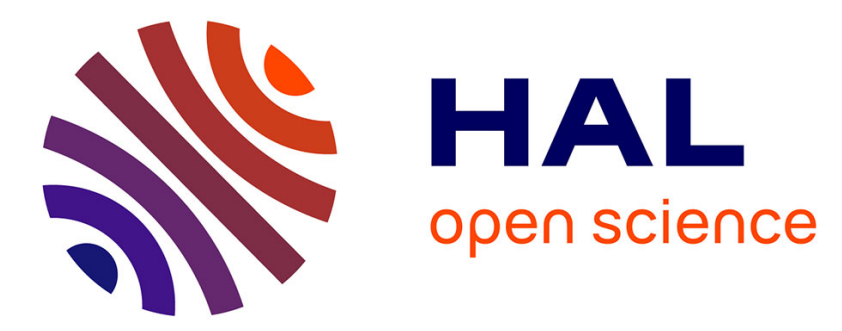

\title{
"What difference does it make (to be in the Middle Income Trap)?": An empirical exploration of the drivers of growth slowdowns
}

\author{
Riana Razafimandimby Andrianjaka, Eric Rougier
}

\section{To cite this version:}

Riana Razafimandimby Andrianjaka, Eric Rougier. "What difference does it make (to be in the Middle Income Trap)?": An empirical exploration of the drivers of growth slowdowns. Structural Change and Economic Dynamics, 2019, 51, pp.225 - 236. 10.1016/j.strueco.2019.08.001 . hal-03488897

\section{HAL Id: hal-03488897 https://hal.science/hal-03488897}

Submitted on 21 Dec 2021

HAL is a multi-disciplinary open access archive for the deposit and dissemination of scientific research documents, whether they are published or not. The documents may come from teaching and research institutions in France or abroad, or from public or private research centers.
L'archive ouverte pluridisciplinaire HAL, est destinée au dépôt et à la diffusion de documents scientifiques de niveau recherche, publiés ou non, émanant des établissements d'enseignement et de recherche français ou étrangers, des laboratoires publics ou privés.

\section{(ㄷ)(1) $\$$}

Distributed under a Creative Commons Attribution - NonCommerciall 4.0 International 


\section{"What difference does it make (to be in the Middle Income Trap)?": An empirical exploration of the drivers of growth slowdowns}

Given name: Riana

Family name: Razafimandimby Andrianjaka

riana-ny-aina.razafimandimby@u-bordeaux.fr

Affiliation: GREThA, University of Bordeaux, Avenue Léon Duguit - 33608 Pessac - France

Given name: Eric

Family name: Rougier

eric.rougier@u-bordeaux.fr

Affiliation: GRETHA, University of Bordeaux, Avenue Léon Duguit - 33608 Pessac - France

\section{Corresponding author:}

Riana Razafimandimby Andrianjaka

riana-ny-aina.razafimandimby@u-bordeaux.fr 


\begin{abstract}
Persistent growth slowdown, generally called Middle-Income Trap (MIT), is a growing concern for middle income countries' governments and for regional and international development banks. This paper (i) uses a mixed approach to identify episodes of MIT in a five-year period panel of 132 countries covering the 1960-2010 period and (ii) tests empirically various explaining factors linked to productive change that have been put forward by the recent literature. Our identification approach consists in comparing the impact of a variety of productive factors on medium-run GDP growth inside and outside the MIT. We find that the demographic drag, skill misallocation and the patterns of export diversification help explain why some middle income countries underwent or are still undergoing persistent growth slowdowns. Our results are robust to various specification and sampling changes.
\end{abstract}

Keywords: Middle income trap, growth slowdown, skill misallocation, structural change, export diversification

JEL classification: C33, O40, O54 


\section{Introduction}

Over the latter five decades, many formerly poor countries could reach intermediate positions in the global scale of income ${ }^{\mathrm{i}}$. Although deeply heterogeneous, all middle-income economies have achieved significant progress in terms of health, education, poverty reduction, agricultural productivity during this period. They also have started diversifying their economy and integrating it to global markets. However, despite these visible changes, out of the 101 countries that were classified as middle-income economies in $1960^{\mathrm{ii}}$, only 13 had reached the higher income group in 2010, with the few successful transitions being concentrated in Europe and East Asia (World Bank, 2012). Indeed, most of the middle income countries (MICs) had to face lingering growth slowdowns after the 1980s that prevented them from catching up with higher income countries (Rodrik, 1999). Persistent growth slowdown has become so pervasive among middle-income economies that the literature has described them as middle-income traps (hereafter MITs) from the late 2000s onwards (Gill and Kharas, 2007, Flaaen et al, 2007; Woo, 2009; Eichengreen et al, 2011; Fang, 2012; Jimenez et al, 2012; Lin and Treichel, 2012; Kanchoochat and Intarakumnerd, 2014, Alias et al, 2014; Agénor, $2017)^{\mathrm{iii}}$.

So far, the empirical literature on MITs has essentially sought to identify MIT episodes in the income per capita convergence framework, without necessarily looking at their causes ${ }^{\text {iv }}$. Whereas the first approach has consisted in identifying growth slowdowns from structural breaks in time series (Rodrik, 1999; Pritchett, 2000, Eichengreen et al. 2012), the second approach has focused its identifying catch-up failures, that is growth trajectories that do not fit the projections made on the basis of unconditional or conditional convergence models. While some papers could identify persistent growth slowdowns in various developing regions (Aiyar et al., 2013; Robertson and Ye, 2013), others have casted doubts about the true existence of 
MITs by pointing out statistical issues (Rosenblat and Im, 2013; Pritchett and Summers, 2014) or by assimilating growth slowdowns in middle-income economies as segments of the convergence trajectory towards long-term level of income per capita (Alias et al., 2014) or of the transition from lower- to higher-levels of economic development (Bulman et al., 2015).

Although this body of empirical evidence could point to the cross-country heterogeneity of growth slowdown episodes, it seldom endeavored to explain why slowdowns happen or not in different middle-income economies. The MIT can be theoretically defined as a stable equilibrium occurring at middle income levels and articulating low growth, slow structural change and arduous policy transitions. Obviously, MICs have to face highly specific economic difficulties that may explain why they undergo enduring economic growth slowdown episodes. Indeed, they must deal with handicaps specific to lower income countries, like the persistence of weakly productive activities or limited access to finance while, in the same time, enduring new difficulties, like declining competitiveness in laborintensive industries or unsuitable governance hindering innovation, imposed by the process of structural transformation and integration to the world economy. The present paper proposes an empirical investigation of the core explanation of MITs, the one related to the patterns of growth and productive transformation. Our method consists in identifying in a large panel of 132 countries over 1960-2010 episodes of MIT defined as spells of persistent growth slowdown by relying on conditions that are now standard in the literature. Based on this identification, we check whether the impact of various factors related to productive transformation is different inside and outside the MIT. We find evidence that the patterns of productive use of skills, the demographic drag and the specific patterns of productive change and diversification all help explain why some middle countries undergo persistent growth slowdowns akin to MITs. 
To our knowledge, our paper is one of the very first empirical investigations of the main productive mechanisms underlying MITs. Indeed, the literature dealing with the mechanisms explaining MITs is emerging and, as such, it is still fairly heterogeneous, methodologically speaking, and hardly conclusive.

First, a series of symptoms shared by countries trapped in enduring slow growth spells was listed (Jiang, 2011; Bulman et al., 2015; Agénor, 2017), most of these symptoms pointing to the productive or policy patterns impeding the transition to the innovation-based growth model $^{\mathrm{v}}$. Although highly relevant, these symptoms are generally based on impressionist evidence drawn from country surveys, and no attempt is made to test empirically and hierarchize these candidate explanations.

Second, various structural determinants have been investigated in order to explain medium run growth acceleration or slowdown spells, without explicitly referring to MITs ${ }^{\mathrm{vi}}$. In Hausmann et al. (2006), for example, the probability of growth acceleration increases with political regime change while it is not impacted by economic reforms. Reddy and Minoiu (2007) find that the probability of stagnation is higher for the countries located in regions (including Latin America and Sub-Saharan Africa) featuring more conflicts and higher dependence on primary goods exports. More recently, Berg et al. (2012) found that trade liberalization, competitive exchange rates, export sophistication, foreign investment and income equality increase the time length of growth acceleration episodes.

Third, a few papers have adopted original approaches in order to address empirically the specificity of MITs. For Berg et al. (2012), the determinants of MITs should be analyzed as systems rather than by isolating single mechanisms (Williamson, 2011), growth slowdown coming from a large variety of cumulative shocks like external crises, civil conflicts, 
structural bottlenecks or poor governance, that may be mutually self-reinforcing. This means that all policy-level controls should be introduced in estimations and that various cumulative effects should be tested. However, the absence of theoretical guidance in the selection of MIT determinants and in the way their combination drives traps was recently pointed by Han and Wei (2017). The absence of a clear theoretical distinction between models of multiple equilibria, such as poverty trap models ${ }^{\mathrm{vii}}$, and multiple steady state models drawn from longterm growth theory was also pointed by Rodriguez (2008) or Blum et al. (2006). Although partially relevant, this argument should not invalidate empirical studies based on theoretical intuitions, as long as these intuitions are rooted into recent economic growth and structural change theories. Moreover, although non-parametric approaches might be useful to explore without a priori the determinants of MITs and their pattern of articulation (Han and Wei, 2017), they tend to place excessive confidence on the relevance of the policy and outcome proxies they use as well as on the quality of the statistical measurement they rely upon. Using theory as a guiding frame might help reducing the information distortion due to the use of rough proxies. The same is true of the assumptions about cumulative effects that can be drawn from the economic theory, as we do in the present paper. Both theory-based parametric and data-based non-parametric approaches need to be investigated and their results should be compared against each other.

The rest of the paper is structured as follows. Section 2 explains our identification method consisting of empirically comparing medium run growth patterns inside and outside the MIT. Then, sections 3 and 4 test if countries in the MIT share or not distinctive features with respect to the growth engines and productive transformation, the two main suspects for explaining MITs, before section 5 concludes. 


\section{What difference do productive structures make? An overview of the productive symptoms of MIT}

The present paper seeks to identify some of the most crucial mechanisms driving to MIT by focusing on the productive dimension. Countries in the MIT have reached a stage of development at which the structures, endowments and institutions that had initially promoted growth are no longer effective in sustaining it (Flaaen et al., 2007; Gill and Kharas, 2007, 2015; Agénor, 2017). Growth slows down in middle income countries because inadequate patterns of factor accumulation and economic growth are not removed, thereby generating dynamic inefficiencies that will eventually make it more difficult to remove them. Inadequate productive structures and economic policies may therefore be responsible for the slow or absent transition from the extensive growth pattern, based on technological imitation and broad-based mobilization of unskilled labor and physical capital, to a more intensive pattern relying on technological innovation and skills (Doner and Schneider, 2016).

Innovation-based and skill-based growth is theoretically supported by larger educational endowment. Long-run growth is supported by investment in primary and secondary education, which spurs investment in imitation capabilities, in developing countries, while the ability to produce advanced technology is spurred by investment in tertiary education when the country gets closer to the technological frontier (Vandenbussche et al., 2006). Agénor et al. (2012) establishes in a two-sector model that the persistence of the imitation-led pattern in middle-income economies might well generate a stable low-level equilibrium called 'imitation trap'. Narrow productivity and wage differentials between the innovation and imitation sectors constrain individual investment in the advanced skills that would be required to be employed in the innovation sector. As high-ability individuals remain under-employed 
in the imitation sector, investment in public infrastructures complementary to skills (like transport or information networks) does not increase skilled labour productivity and the innovation sector fails to expand. Indeed, skill misallocation is highly typical of the middleincome economies which have heavily invested in secondary and tertiary education, while their productive system is feebly absorptive of the increasing skilled workforce (Eckhout and Jovanovic, 2012).

Demographic transition also stands as a potential reinforcing factor of skill misallocation and a potential driver of persistent growth slowdown and in middle-income countries. Furuoka and Munir (2011) have identified positive reinforcement mechanisms between population growth and structural change as, by increasing potential market size, population growth triggers competition between firms and investment in new activities. However, the population age structure also matters since, as inactive children and pensioners are poorly contributive to wealth generation and saving, high dependency ratios will hinder medium-run growth (Leff, 1969). Conversely, provided young workers are sufficiently endowed in physical and human capital, a demographic dividend may appear at intermediate stages of the demographic transition, as constraints on savings, productive investment and labor supply progressively

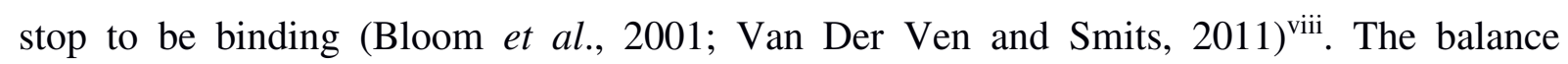
between the demographic drag and dividend is thus conditional on the physical and human capital endowment of new workers, as well as on the correct matching of skill supply and demand, which eventually depends on the pace of productive transformation. In the middleincome economies where productive transformation is slow, the dearth of employment opportunities for young and skilled workers might prompt politico-economic instability (Campante and Chor, 2012) or, on the contrary, persistent authoritarian-redistributive political economies (Rougier, 2016), both thwarting medium-run growth. 
Issues related to productive transformation characterizing middle-income countries have also been described by the 'scissor' effect. According to Gill and Kharas (2007, 2015), middle income countries tend to be squeezed between low-wage competitors dominating mature industries and advanced innovators dominating skill-intensive industries. Along the path from lower- to middle-income levels, broad-based physical capital accumulation gradually modifies relative factor prices and comparative advantage towards more capital-intensive goods (World Bank, 2012; Schott, 2003; Lin, 2009, 2012). One unintended consequence is that former comparative advantage relying on cheap labour starts vanishing at the time when skill-intensive industries are not yet competitive (Agénor et al., 2012; Eichengreen et al., 2011, 2013). Productivity slowdown in middle income economies may thus be explained by the simultaneous loss of comparative advantage in labor-intensive industries consecutive to rising wages and weakness of new comparative advantage in skill-intensive industries (Gill and Kharas, 2007; Spence, 2011; Kharas and Kohli, 2011; Felipe et al., 2012). Consequently, deeper trade integration may not be as beneficial to middle income economies, which lack of sound comparative advantage, as it may be to the lower- or higher-income economies, as the latter are endowed with firmer comparative advantage than the former (Kharas et al., 2010; Udomsaph and Zeufack; 2010; Felipe et al., 2012; Jankowska et al., 2012).

Productive diversification is a crucial driver of growth slowdown or acceleration in middleincome countries, as was evidenced by Felipe et al. (2012). Still, the relationship is not straightforward as middle-income economies' productive system may be diversified but not necessary fully efficient and competitive. As put forward by Hausmann and Rodrik (2003), middle-income economies start diversifying their production before they start rationalizing it by facilitating the market-based selection of competitive industries. As was evidenced by Imbs and Wacziarg (2003) or Cadot et al. (2011a), productive transformation is first driven by 
output and export diversification along the extensive margins, output and export diversification reaching their maximum level at intermediate levels of economic development. This may drive economic growth for a while, before inefficiencies and lack of competitiveness reduce the growth divide of diversification. For most middle income countries, further upgrading production and trade therefore requires diversification along the intensive margins (Cadot et al., 2011a) and productive re-concentration through rationalization and selection of the most productive industries and firms (Hausmann and Rodrik, 2003). Indeed, according to Gill and Kharas (2015: 7), the fact that economies tend to re-specialize at higher-middle income level is the most important lesson from Imbs and Wacziarg (2003). This lesson has tended to be ignored by policy-makers in many middleincome countries who seek to encourage the rise of new industries distant from the country's comparative advantage, through vertical or assembly FDI, with only weak impacts on productive rationalization and sophistication, as was recently evidenced by Lectard and Rougier (2018).

From this review of the theoretical and empirical literature related to productive issues in middle income countries, we can draw a set of candidate explanations of MITs that will be tested in the next section. Indeed, we will check whether human capital misallocation, the demographic dividend, and productive diversification help explain the difference in growth regime between the countries within the MIT and those outside.

\section{Who is caught in the MIT and what difference does it make in terms of GDP growth?}

\subsection{Who is caught in the MIT? Methodological issues}

Before investigating the drivers of persistent growth slowdown in middle-income economies, we need to identify these episodes from time-series data for the 132 countries of our sample. 
The different papers having identified the countries allegedly located in the MIT have tried to find breaks in GDP time series by mobilizing two contrasted approaches.

The first approach consists in identifying breaks ${ }^{\mathrm{ix}}$ in GDP or productivity growth trajectories. This first set of studies have essentially adopted an absolute definition of divergence to identify structural breaks in growth time series. Pritchett (2000) ranks for example growth episodes into various patterns, with "plateaus", i.e. spells of average growth rate over $1.5 \%$ before the structural break but less than $1.5 \%$ thereafter, possibly corresponding to MITs. Nonetheless, Rosenblat and Im (2013) could not find a common growth configuration of a plateau-type across the countries identified as being caught in the MIT. relies on a priori definitions of the criteria defining MITs. Eichengreen et al. (2012) defines MITs as countries whose income per capita is above $\$ 10,000$ and undergoing a growth slowdown satisfying two conditions: an average GDP growth rate of $3.5 \%$ or more during the seven-year period prior to the slowdown and a $2 \%$ drop of GDP growth at least from the break onwards. In a different vein, Felipe et al. (2012) uses the number of years a country was classified a lower- or uppermiddle income to identify a duration threshold above which (and a growth rate threshold below which) a country is supposed to be trapped.

The second approach identifying MITs by assessing growth slowdown relatively to other economies has led to fairly contrasted results. By defining MIT as a country lying in the middle income band having a mean growth rate of income relative to the USA not significantly different from zero, Robertson and Ye (2013) could find that more than one half of the middle-income countries of their sample matched the definition. By estimating the extent and length of negative deviations from the predicted growth path and identifying them as MITs if they are sufficiently pronounced to place the period observed in the smallest quintile of change in residuals between two successive years, Aiyar et al. (2013) also 
identifies growth slowdown spells that match the stylized facts of traps observed in various developing regions over 1975-85. Some other papers, also relying on the convergence theory, were less conclusive. By estimating transition probabilities and durations with respect to sample countries' initial income and growth rate differential with the frontier, Rosenblat and Im (2013) have found for example that transitions from middle to higher income are as likely as transitions from lower- to middle-income, with transition duration being not significantly longer for the former. Likewise, Pritchett and Summers (2014) have shown that episodes of growth slowdown at middle-income level are better explained by regression to the mean than by the alleged middle-income trap.

Identification based on relative criteria is uneasy and the debate as to which method is the best method has not been settled down so far. In order to address the duration and magnitude of growth slowdowns at middle-income levels, we have chosen to combine the two former approaches reviewed above that are more transparent. We first look GDP growth time series for an extensive set of countries to identify slowdown episodes using similar criteria of breakdown year and slowdown duration as in Eichengreen et al $(2012,2014)^{\mathrm{x}}$. Then, we define income per capita conditions so as to limit the relevant growth slowdown set to middle-income countries. As in Felipe et al (2012), we consider that the episodes of middle income growth slowdown thus identified correspond to MITs if they fit a threshold of slowdown duration. Combining these two approaches enables identifying a subset of countryyear identified as enduring slowdown episodes at middle income level and a subset of country-year outside enduring slowdown episodes on which various candidate explaining factors can be tested.

We therefore start by identifying breakpoints defined as years featuring a significant slowingdown of GDP growth from national time series. For comparison sake, we consider as in 
Eichengreen et al. $(2012,2014)$ an episode of growth slowdown when GDP growth rate fulfills two conditions:

(C1) $g_{t-n, t} \geq 0.035$,

(C2) $\mathrm{g}_{t-n, t}-\mathrm{g}_{t, t+n} \geq 0.020$,

Where $\mathrm{g}_{t-n, t}$ is the average growth rate of GDP per capita between times $t-n$ and $t$, and $\mathrm{g}_{t, t+n}$ the average growth rate between times $t$ and $t+n$. As in Eichengreen (2012), we set $n$ to 7. C1 implies that the average growth rate of the seven-year window prior to the breakpoint year should be at least $3.5 \%$. C2 defines a growth slowdown as a decline of at least $2 \%$ points of the average growth rate during at least seven years after the break year. This condition implies that the growth slowdown has to be both substantial and sustained to be considered as a $\operatorname{MIT}^{x i}$

Eichengreen et al. (2012) have added the condition as to GDP per capita must be greater than $\$ 10,000$. As Agénor (2017), we consider this is too high a threshold since it would evacuate from the analysis a bunch of lower middle-income countries that may be trapped in low growth equilibrium akin to MITs. Instead, we use a more fine-grained filter enabling to differentiate our results for the lower- and upper-middle income categories. Although useful, the World Bank classification of income categories was not directly applicable to our data since it is based on the gross national income (GNI) per capita series while we use gross domestic product (GDP) per capita ${ }^{\mathrm{xii}}$. To establish our thresholds, we follow Felipe et al. (2012) and compute a correspondence between the GNI and GDP thresholds from the Maddison dataset. Using data from 1987 to 2010, we have (i) assigned countries based on their 1990 GDP per capita measured in PPP in their income category for 10,080 different sets of thresholds ${ }^{\mathrm{xiii}}$, (ii) computed the pair-wise correlations between these 10,080 classifications 
and the official World Bank classifications, and (iii) selected the set of thresholds showing the strongest correlation (0.9741) with the official World Bank classification: low-income countries have per capita GDP below $\$ 2,000$, lower-middle-income countries have GDP per capita standing between $\$ 2,000$ and $\$ 7,250$, upper-middle-income countries have GDP per capita between $\$ 7,250$ and $\$ 11,250$ and higher income countries have per capita GDP above $\$ 11,250$

Accordingly, a condition (C3) is added, restricting MITs to the years when the country satisfying conditions $\mathrm{C} 1$ and $\mathrm{C} 2$ is located at lower- and upper-middle-income levels:

(C3) $\$ 2,000 \leq \mathrm{y}_{T}<\$ 7,250$ or $\$ 7,250 \leq \mathrm{y}_{T}<\$ 11,250$, where $\mathrm{y}_{T}$ is the per capita GDP in year $T$ (expressed in PPP adjusted constant 1990 dollar), with $t<T<$ $t+n$ and $n=7$ as in conditions (2) and (3).

The first year that a country meets the three conditions $\mathrm{C} 1, \mathrm{C} 2$ and $\mathrm{C} 3$ is taken as the year of entry into a MIT episode. MIT status is thus attributed to any middle-income country having experienced a slowdown episode whose duration is above the sample mean duration. Countries are therefore considered to be trapped into a middle-income trap if they have remained more than 30 years in the middle-income category over $1950-2010^{\mathrm{xiv}}$. Out of the 78 countries of our sample, 23 countries have undergone a MIT episode between 1960 and 2010 (Table A6 in Appendix).

3.2. What difference does it make to be caught in the MIT? Identifying medium run growth patterns inside the trap

The present paper proposes a simple empirical approach consisting in comparing the impact of various candidate explanations of the persistent growth slowdown characterizing the MIT 
and the transition from intermediary to higher income levels. Our intuition is that the growth impact of various factors may be different in the MICs inside and outside the trap. By estimating equation 1 below, we seek to identify the extent to which the medium-run growth impact of each determinant $\mathrm{X}$ identified by the MIT literature is different for the middleincome countries inside the trap than for the rest of the sample:

GDP growth ${ }_{i, t-t+5}=\alpha_{1} * Z_{i, t-t+5}+\alpha_{2} * \operatorname{MIT}_{i, t-t+5}+\alpha_{3} * X_{i, t-t+5}+\alpha_{4} * \operatorname{MIT}_{i, t-t+5} * X_{i, t-t+5}+\mu_{i}+v_{t-t+5}+$ $\varepsilon_{i t-t+5}$

In Equation 1, country $i$ 's medium-run growth prospect between $t$ and $t+5$, measured by the average growth rate over each five-year spell, is successively regressed on each MIT driver $\mathrm{X}_{i, t-t+5}$, on its interaction $\operatorname{MIT}_{i, t-t+5} * \mathrm{X}_{i, t-t+5}$ with the MIT dummy variable and on a Z-set of time-varying contemporaneous standard growth controls: the initial level of GDP per capita, controlling for convergence, population growth, the skill ratio and investment rate controlling for traditional growth drivers, and trade openness controlling for both institutional quality and economic policies $^{\mathrm{xv}}$. The dummy variable MIT takes the value 1 for the country-year individual observations meeting the different conditions of a MIT episode as identified in previous section 3. For example, consider a country that has been into the middle-income category since 1972, started a growth slowdown in 1975 lasting 31 years, while remaining middle-income meanwhile. Years from 1975 to 2006 will be coded 1 while those from 1972 to 1975 and after 2006 are coded 0, and the five-year intervals 1975-1980, 1980-1984, 1985$1989,1990-1994,1995-1999,2000-2004$ will consecutively take the value one, whereas the interval 2005-2009 is coded zero as less than 3 constitutive years were coded one.

As explained in the previous section, we test various candidate determinants of the sustained middle income growth slowdown that have been advanced by the recent literature. They are 
all related to the pattern of structural change along the development path, covering such issues as the shift from a regime of factorial accumulation and output growth based on physical capital to a growth regime based on skill-intensive industries and technological innovation, skill misallocation issues or the deficit of productive transformation and its trade-related symptoms and determinants.

The method of identification is straightforward: each potential determinant of the MIT is introduced as part of the interaction term with the MIT dummy $\operatorname{MIT}_{i, t-t+5} * X_{i, t-t+5}$, besides traditional controls of GDP growth described above. In equation 1, the estimated coefficient $\alpha_{4}$ therefore identifies the extent to which the impact of any singular growth determinant is minored or magnified for countries inside the MIT, with reference to the estimated impact $\alpha_{3}$ of this very determinant for the middle income countries outside the MIT. This enables comparing the MIT's growth pattern with the one of countries that could successfully avoid or escape the trap and reach higher income levels. We also use a larger reference group labelled "extended" including the middle income economies and the higher income countries not trapped to check the sensibility of our results to the choice of the reference group ${ }^{\mathrm{xvi}}$. Estimations include time and country fixed effects in order to control for time-varying (identical for all countries) and time-invariant (specific to each country) non-observable variables that may affect average GDP growth in the subsequent period. Likewise, coefficient's standard errors are clustered by country.

Estimating a truly dynamic model would allow controlling for catching-up. As evoked in the previous section, growth slowdowns could simply correspond to a process of reversion to the mean of the convergence-type rather than to a MIT. The lagged value of the level of GDP per capita was added to the explaining factors in order to control for convergence. This enables to check that the impact we find is not driven by an uncontrolled catch-up process. 
Lastly, endogeneity issues are addressed by systematically estimating a model with one period (5-year) lag where the dependent variable standing for the average growth rate is measured over $t$ and $t+5$ while the explaining variables are averaged over $t-5, t-1$. Insofar as the risk of reverse causality is limited by the choice of future growth as the dependent variable, we can be confident that our fixed effect estimations measure more than mere correlations, that is different patterns of statistical relation between a series of policy or economic determinants observed at each period and subsequent medium-run growth. Owing to this prudent empirical strategy, we could identify a series of factors which are differently associated to subsequent growth trajectories inside and outside the trap with a fairly relative confidence that they are causal.

The variables we use in our empirical investigations (listed in Table A7), are the following. First, investment rate is the gross capital formation in percentage of GDP. As demographic variables we use alternatively the population growth rate and the youth dependency ratio, which is the ratio of younger dependents (people younger than 15) to the working-age population (those ages 15-64). As proxy for human capital, we calculate a skill ratio which is the ratio of tertiary and secondary education achievement rates. We also run additional estimations using the secondary and education achievement rates. To measure structural transformation, we use the overall, intensive and extensive diversification index (measured by the Theil coefficient) computed by the International Monetary Fund. Higher values of theses indicator means lower diversification. We also introduce a measure of trade openness which is the imports and exports in percentage of GDP. 


\title{
4. What difference do productive structures make? Estimation results
}

\author{
4.1. Differentiated patterns of productive factor use inside and outside the MIT: extensive vs \\ intensive growth and the demographic drag
}

Table 1 reports the results of the estimation of equation 1 for the restricted reference group, including only MICs, which seems the most conceptually sound. Baseline model's estimation reported in equation 1 confirms that countries with higher investment rates, more liberalized economies, lower lagged income per capita and lower population growth rates tend to exhibit higher growth rates. It is worth noticing that, when log-transformed, the estimated coefficient of the lagged level of GDP per capita stands in a range of magnitudes (from .018 to .40) highly consistent with the standard literature on conditional convergence. The estimated coefficient of the MIT dummy shows that 5-year mean GDP growth is on average 2.4 points lower inside the MIT than outside.

The negative coefficient of investment rate for the lagged model would suggest that the positive growth impact identified for the simultaneous model is due to the reverse positive impact of growth on capital accumulation. We checked that using simultaneous investment rate in columns 2 and 4 did not change the results for the other coefficients, notably for the interaction with the dummy MIT.

In Column 2 are reported the estimated coefficients for the lagged model, where all right-hand side variables are five-year lagged, accounting for medium-run impacts of some growth drivers. Although most variables are not significant, coefficient estimates for the initial level of GDP per capita and for the MIT dummy are consistent with those of the simultaneous model of equation 1 (reported in column 1). Estimations of the baseline model therefore 
confirm that countries trapped in the MIT feature lower growth rates than other middle and

higher income countries, which may durably impede convergence.

Table 1: GDP growth drivers, capital and population growth: Fixed Effect estimations of the contemporaneous and lagged models on the restricted sample

\begin{tabular}{|c|c|c|c|c|c|c|c|c|}
\hline & (1) & (2) & (3) & (4) & (5) & (6) & (7) & (8) \\
\hline \multirow{2}{*}{$\begin{array}{l}\text { Dependent: } \\
\text { 5-year av. GDP growth }\end{array}$} & \multicolumn{2}{|c|}{ Baseline } & \multicolumn{2}{|c|}{ Investment rate interaction } & \multicolumn{2}{|c|}{ Population growth interact. } & \multicolumn{2}{|c|}{ Dependency rate interact. } \\
\hline & Contempor. & Lagged & Contempor. & Lagged & Contempor. & Lagged & Contempor. & Lagged \\
\hline Lagged GDP p. cap. & $\begin{array}{c}-1.2 \mathrm{e}-05^{* * * *} \\
(1.8 \mathrm{e}-06)\end{array}$ & $\begin{array}{l}-8.1 \mathrm{e}-06^{* *} \\
(1.9 \mathrm{e}-06)\end{array}$ & $\begin{array}{c}-1.2 \mathrm{e}-05^{* * *} \\
(1.8 \mathrm{e}-06)\end{array}$ & $\begin{array}{c}-5.2 \mathrm{e}-06^{* *} \\
(1.9 \mathrm{e}-06)\end{array}$ & $\begin{array}{c}-1.2 \mathrm{e}-05^{* * * *} \\
(1.8 \mathrm{e}-06)\end{array}$ & $\begin{array}{c}-8.2 \mathrm{e}-06^{* * * *} \\
(1.8 \mathrm{e}-06)\end{array}$ & $\begin{array}{c}-1.3 \mathrm{e}-05^{* * * *} \\
(1.9 \mathrm{e}-06)\end{array}$ & $\begin{array}{c}-8.1 \mathrm{e}-06^{* * *} \\
(1.9 \mathrm{e}-06)\end{array}$ \\
\hline Population growth & $\begin{array}{l}-0.008 * * \\
(0.0036)\end{array}$ & $\begin{array}{l}.0008 \\
(0.004)\end{array}$ & $\begin{array}{l}-0.008 * * \\
(0.0037)\end{array}$ & $\begin{array}{c}-0.0103^{* * *} \\
(0.003)\end{array}$ & $\begin{array}{l}-0.0037 \\
(0.005)\end{array}$ & $\begin{array}{l}0.007^{*} \\
(0.004)\end{array}$ & - & - \\
\hline Skill ratio & $\begin{array}{c}0.006 \\
(0.009)\end{array}$ & $\begin{array}{c}0.007 \\
(0.006)\end{array}$ & $\begin{array}{l}0.0061 \\
(0.009)\end{array}$ & $\begin{array}{l}0.015^{*} \\
(0.007)\end{array}$ & $\begin{array}{c}0.0066 \\
(0.0084)\end{array}$ & $\begin{array}{c}0.008 \\
(0.006)\end{array}$ & $\begin{array}{c}0.0067 \\
(0.0084)\end{array}$ & $\begin{array}{c}0.007 \\
(0.005)\end{array}$ \\
\hline Trade openess & $\begin{array}{r}3.1 \mathrm{e}-04 * * * \\
(9.3 \mathrm{e}-05)\end{array}$ & $\begin{array}{c}4.5 \mathrm{e}-05 \\
(8.2 \mathrm{e}-05)\end{array}$ & $\begin{array}{c}3.1 \mathrm{e}-04 * * * \\
(9.2 \mathrm{e}-05)\end{array}$ & $\begin{array}{l}2.0 \mathrm{e}-04 * * \\
(7.7 \mathrm{e}-05)\end{array}$ & $\begin{array}{c}3.1 \mathrm{e}-04 * * * \\
(9.0 \mathrm{e}-05)\end{array}$ & $\begin{array}{c}6.4 \mathrm{e}-05 \\
(7.6 \mathrm{e}-05)\end{array}$ & $\begin{array}{c}3.0 \mathrm{e}-04 * * * \\
(9.6 \mathrm{e}-05)\end{array}$ & $\begin{array}{c}6.1 \mathrm{e}-05 \\
(7.4 \mathrm{e}-05)\end{array}$ \\
\hline Investment rate & $\begin{array}{c}0.0018^{* * *} \\
(0.0003)\end{array}$ & $\begin{array}{c}-0.0010^{* * * *} \\
(0.0004)\end{array}$ & $\begin{array}{c}0.0019^{* * *} \\
(0.0004)\end{array}$ & $\begin{array}{c}-0.0014 * * * \\
(0.0005)\end{array}$ & $\begin{array}{c}0.0018^{* * * *} \\
(0.0004)\end{array}$ & $\begin{array}{l}-0.001 * * \\
(0.0004)\end{array}$ & $\begin{array}{c}0.0017 * * * \\
(0.0003)\end{array}$ & $\begin{array}{l}-0.001 * * \\
(0.0004)\end{array}$ \\
\hline MIT dummy & $\begin{array}{c}-0.024 * * * \\
(0.005)\end{array}$ & $\begin{array}{c}-0.020 * * \\
(0.007)\end{array}$ & $\begin{array}{l}-0.023 \\
(0.015)\end{array}$ & $\begin{array}{c}0.008 \\
(0.014)\end{array}$ & $\begin{array}{c}-0.01 \\
(0.011)\end{array}$ & $\begin{array}{c}0.006 \\
(0.011)\end{array}$ & $\begin{array}{l}-0.019 \\
(0.015)\end{array}$ & $\begin{array}{c}0.013 \\
(0.019)\end{array}$ \\
\hline MIT*Investment & - & - & $\begin{array}{l}-0.00003 \\
(0.0005)\end{array}$ & $\begin{array}{l}-0.0009 \\
(0.0007)\end{array}$ & - & - & - & - \\
\hline MIT*Population gr. & - & - & - & - & $\begin{array}{c}-0.007 \\
(0.0045)\end{array}$ & $\begin{array}{c}-0.0113 * * \\
(0.0048)\end{array}$ & - & - \\
\hline Dependency rate & - & - & - & - & - & - & $\begin{array}{c}-2.05 e-04 \\
(2.87 e-04)\end{array}$ & $\begin{array}{l}-3.65 \mathrm{e}-06 \\
(2.74 \mathrm{e}-04)\end{array}$ \\
\hline MIT*Dependency & - & - & - & - & - & - & $\begin{array}{l}-8.18 \mathrm{e}-05 \\
(2.20 \mathrm{e}-04)\end{array}$ & $\begin{array}{l}-4.38 \mathrm{e}-04^{*} \\
(2.39 \mathrm{e}-04)\end{array}$ \\
\hline Constant & $\begin{array}{c}0.036^{* * *} \\
(0.013) \\
\end{array}$ & $\begin{array}{c}0.076^{* * *} \\
(0.011) \\
\end{array}$ & $\begin{array}{c}0.035^{* * *} \\
(0.016) \\
\end{array}$ & $\begin{array}{c}0.085^{* * *} * \\
(0.014) \\
\end{array}$ & $\begin{array}{c}0.024 \\
(0.016) \\
\end{array}$ & $\begin{array}{c}0.060 * * * \\
(0.011) \\
\end{array}$ & $\begin{array}{c}0.039 \\
(0.026) \\
\end{array}$ & $\begin{array}{c}0.078 * * * \\
(0.022) \\
\end{array}$ \\
\hline Obs. & 261 & 255 & 261 & 255 & 261 & 255 & 261 & 255 \\
\hline Number of groups & 49 & 49 & 49 & 49 & 49 & 49 & 49 & 49 \\
\hline Adj. R-squared & 0.34 & 0.06 & 0.44 & 0.25 & 0.45 & 0.37 & 0.43 & 0.37 \\
\hline Country FE & YES & YES & YES & YES & YES & YES & YES & YES \\
\hline Time FE & YES & YES & YES & YES & YES & YES & YES & YES \\
\hline Marg. impact ${ }^{a}$ & & & $\mathrm{X}_{1}$ : Inve & ment rate & $\mathrm{X}_{1}$ : Popul & ion growth & $\mathrm{X}_{1}$ : Deper & dency ratio \\
\hline MIT: $X_{1}$ & - & - & +.38 & - & NS & -.28 & NS & -.33 \\
\hline non-MIT: $\mathrm{X}_{1}$ & - & - & $\begin{array}{r}+.41 \\
\end{array}$ & - & NS & $\begin{array}{r}+.48 \\
\end{array}$ & NS & NS \\
\hline
\end{tabular}

Robust standard errors in parentheses; Restricted means that the comparison group is limited to MICs not in the MIT; Extended means that the restricted comparison group is extended to HICs; a) the marginal impact of the variable X interacted with the MIT dummy in the corresponding column measures the (in terms of standard deviation) variation of GDP growth rate for a one standard deviation increase of X (at the mean value of all other regressors); in bold are reported the marginal impacts that are statistically different for the MIT and non-MIT samples; *** $\mathrm{p}<.01$, ** $\mathrm{p}<.05, * \mathrm{p}<.10, \mathrm{NS} \mathrm{p}>.10$

Extending the estimation sample to higher income countries (hereafter HICs) (Table A1's columns 1 and 2) leads to fairly similar results for the lagged levels of GDP per capita, the 
MIT dummy, trade openness and the investment rate, whenever the model is simultaneous or lagged. Interestingly, the skill ratio becomes driver of growth, while it was not significant in the MICs subsample, and the adverse impact of population growth reverses to a positive one in the extended sample (albeit only in the lagged model). This suggests that, in the sample including HICs, population growth plays more as a spur than as a drag and that the general pattern of growth is more skill-intensive than in the sample containing only MICs.

Table 1's remaining columns 3 to 8 investigate further the extent to which growth patterns differ inside and outside the MIT with respect to the standard drivers of extensive growth, namely the investment and population growth rates and the dependency ratio. At the bottom of each column are reported the marginal growth impact (in terms of GDP growth standard deviation) of a one standard deviation increase of the $\mathrm{X}$ driver of interest - derived from the corresponding column's estimation and computed at the mean value of all other regressors for the MICs inside and outside the MIT. When X has a statistically different growth impact across the two subsamples, the pair of marginal impacts is reported in bold character.

First, the coefficient of the interaction variable MIT*investment in table 1's column 3 and 4 is not significant, suggesting that investment has a similar impact on growth in the MICs trapped and not trapped. However, the pattern is different when the reference sample is extended to higher income countries since the growth impact of investment is more than twotimes larger in the MIT than in the rest of the sample, as we can see in the figures of Table A1's column 3. This suggests that the growth pattern inside the MIT is more extensive than in the group composed of MICs not trapped and of higher-income countries. Re-computing the magnitudes of the predicted impacts is equally insightful: a one standard deviation increase of the average investment rate will lead to a .39 standard deviation increase of the average GDP 
growth in the MICs in the MIT, against .17 standard deviation increase for the MICs not trapped and the HICs.

Results for population growth and the dependency ratio provide additional support to the assumption of an extensive pattern of growth in the MIT. Estimates reported in Table 1's column 6 show that five-year lagged population expansion tends to reduce GDP growth inside the MIT, while triggering growth outside the MIT. In terms of magnitude, the gap is large as a one standard deviation increase of the dependency ratio leads to a .28 standard deviation drop of the GDP growth rate inside the MIT while prompting a .48 standard deviation increase of the GDP growth rate for the MICs outside the MIT ${ }^{\mathrm{x} v i i}$.

Besides, the significant coefficient of the interaction term in Table 1's column 8 suggests that this adverse growth impact might be driven by the dependency ratio. A one standard deviation increase of the dependency ratio leads to a .33 standard deviation decrease of the average growth rate inside the MIT. The impacts are very similar in both direction and magnitude when the comparison group is extended to HICs (Table A1's columns 8) as a one standard deviation increase of the dependency ratio in the preceding five-year period leads to a .34 standard deviation drop of the average growth rate inside the MIT.

For the same level of investment, our estimations say, countries featuring faster population growth or higher youth dependency ratio have lower growth rates inside the MIT than outside the MIT. This would mean that slower growth in the MIT subsample could be explained by a dearth of physical capital per worker ${ }^{\text {xviii }}$. In the rest of this section, we check whether the adverse growth effect of population dynamics observed inside the MIT relaxes or persists when physical and human capital endowments increase. Indeed, moderation of the negative growth impact of the population dynamics and structure when investment rate and the skill 
ratio increase would mean that the demographic drag on growth might be attributed to the lack of physical or human capital per young worker. In order to test this assumption, we estimate the equation 2 which is an adaptation of the baseline equation with triple interactions $\operatorname{MIT}_{i, t} * \mathrm{X}_{1 i, t} * \mathrm{X}_{2 i, t}$ xix:

(2) GDP growth $=\alpha_{1} * Z_{i, t}+\alpha_{2} * \operatorname{MIT}_{i, t}+\alpha_{3} * \mathrm{X}_{1 i, t}+\alpha_{4} * \mathrm{X}_{2 i, t}+\alpha_{5} * \mathrm{MIT}_{i, t} * \mathrm{X}_{1 i, t} * \mathrm{X}_{2 i, t}+$

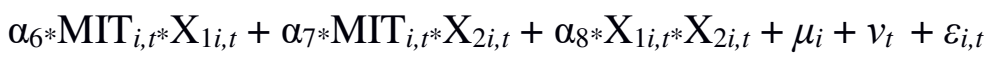

Figure 1: Predicted impacts of population growth for various levels of the investment rate (1a) and of the skill ratio (1b): MIT vs non-MIT

Panel 1a: Population growth*investment rate (simultaneous model - extended sample)

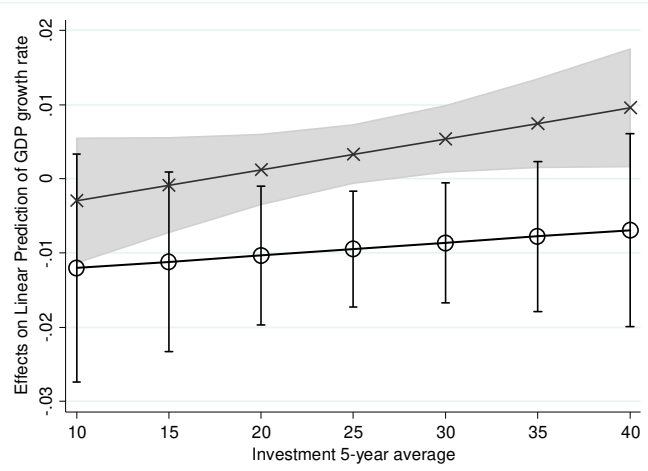

Panel 1b: Population growth*skill ratio (simultaneous model - restricted sample)

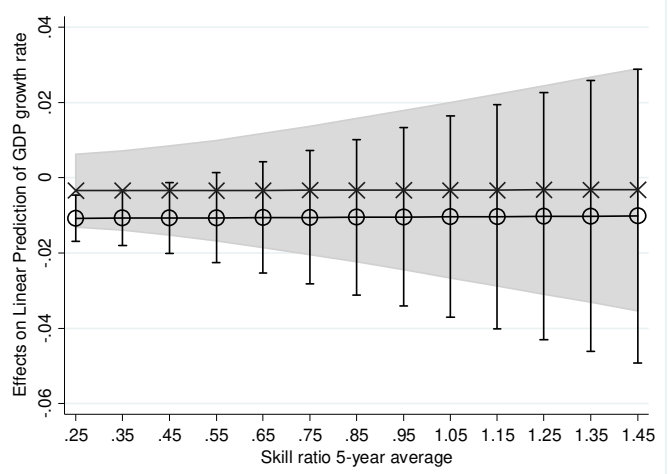

Panel 1c: Population growth*skill ratio (lagged model - restricted sample)
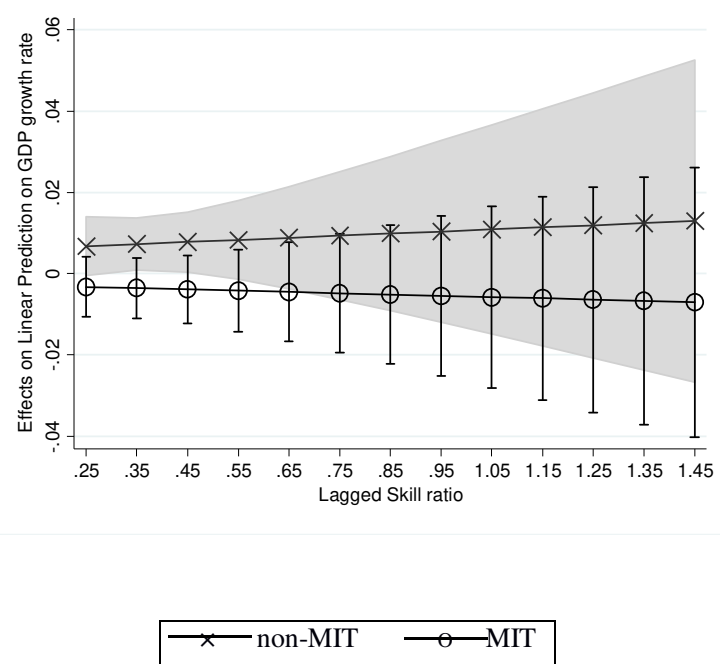
Then, we compute from these estimations the predicted marginal impact of population growth for various levels of the investment rate and of the skill ratio, for the MIT and the non-MIT complementary sub-samples ${ }^{\mathrm{xx}}$. These conditional marginal impacts are reported in figure $1^{\mathrm{xxi}}$. As illustrated by panel 1a, the growth impact of population expansion is positive and increasing outside of the MIT, with statistical significance being limited to the highest region of the investment rate distribution (higher than $28 \%$ of GDP) corresponding to the top $5 \%$ of the extended reference sample. By contrast, inside the MIT, the predicted growth impact of population expansion remains negative and fairly unchanged, even for investment rates comprised between 20 and $30 \%$ xxii , suggesting that the dearth of capital per worker is not the channel through which population expansion reduces GDP growth ${ }^{\mathrm{xxiii}}$.

Our findings in this section suggest that the MICs that fail to modify substantially the extensive pattern of growth are more likely to face enduring spells of growth slowdown. The standard drivers of GDP growth are fairly differentiated, albeit to various extent, inside and outside the MIT. Capital accumulation proves more prominent inside than outside the MIT, and population growth acts as a true drag on medium run growth, probably because youth dependency plays more as a burden than as an opportunity. Our estimations in this section therefore suggest that the adverse impact of population expansion and dependency ratios on economic growth characterizing countries in the MIT can be explained by their failure to capture the demographic divide. The non-linear estimations presented at the end of the section support the assumption that this failure may be due to the dearth of human capital per worker. In the next section, we look more closely at the patterns of productive diversification inside and outside of the MIT and discuss additional indications of the skill misallocation issue. 


\subsection{Differentiated patterns of productive diversification: More on skill misallocation}

The productive structure, and its pattern of transformation, is a crucial driver of medium run growth in middle income countries. Export diversification is a relevant indicator of the productive structure transformation as it measures the capacity of a country's firms to produce new products and to sell them competitively on external markets. However, we know that after a long phase of diversification, generally based on extensive margins and on extensive growth patterns, both export and production need to concentrate, growth must become more intensive, competition more stringent and firms more productive if the MIC wants to catch-up with HICs (Imbs and Warcziag, 2003; Cadot et al., 2011a). According to the scissor effect, MICs will find it harder than other countries to switch from labor-intensive and resourceintensive specializations, on which they lost their comparative advantage to the benefit of low-wage countries, to skill-intensive and innovation-intensive specializations, on which their comparative advantage is still limited with respect to skill-rich and innovation-led economies (Gill and Kharas, 2007, 2015; Spence, 2011; Kharas and Kohli, 2011). MICs may therefore experience a growth slowdown before their transition from diversification to re-concentration is achieved (Hausman and Rodrik, 2003).

Figure 2, plotting the overall Theil index of export concentration against contemporary level of GDP per capita for the whole sample, confirms that export concentration first decreases and then increases during the course of economic development. A closer look at the panels $b$ and $\mathrm{c}$ of the figure 3 also reveals that export concentration tends to be lower in the MICs in the MIT than in the rest of MICs, and that most countries in the MIT are still engaged in the diversification phase, characterizing the single LICs (panel a), while a substantial proportion of the MICs not trapped have reached the concentration phase characterizing HICs (panel d). 
Figure 2: Scatterplot of Theil of concentration versus GDP per capita for the whole sample

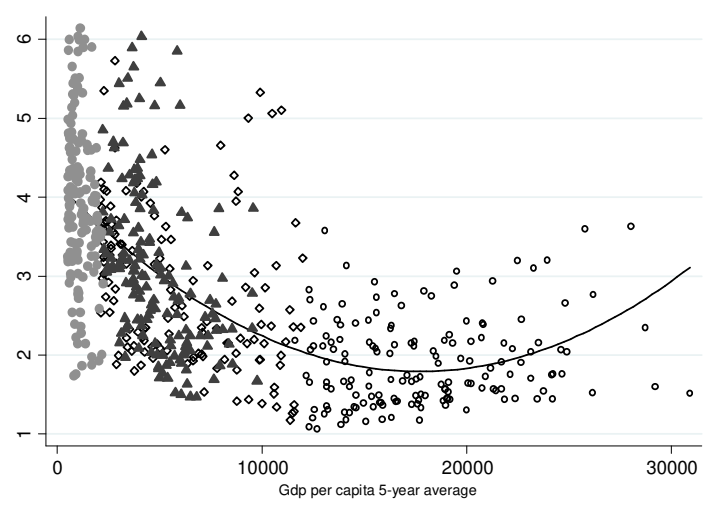

\begin{tabular}{|llll|}
\hline Fitted values & $\boldsymbol{\Delta}$ & Middle-Income countries in the MIT \\
& Low-Income Countries & $\diamond$ & Middle-Income Countries not in the MIT \\
High-Income Countries & & \\
\hline
\end{tabular}

Figure 3: Scatterplots of Theil of concentration versus GDP per capita for the different subsamples

Panel a. Lower income countries

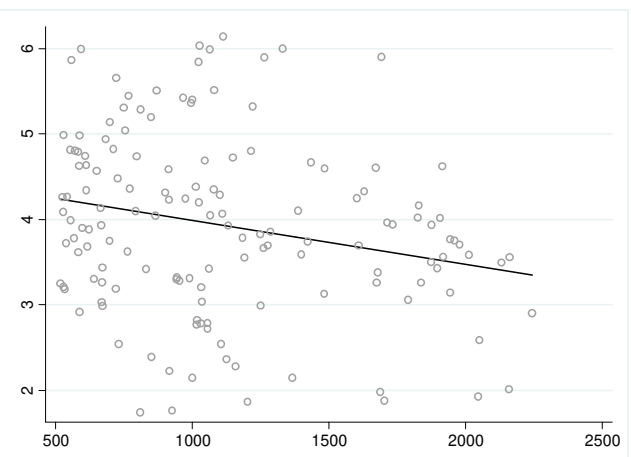

Panel c. Middle income countries non-MIT

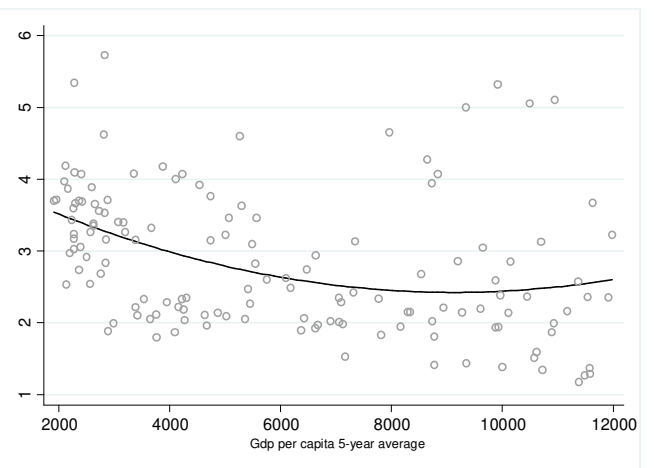

Panel b. Middle Income Trap

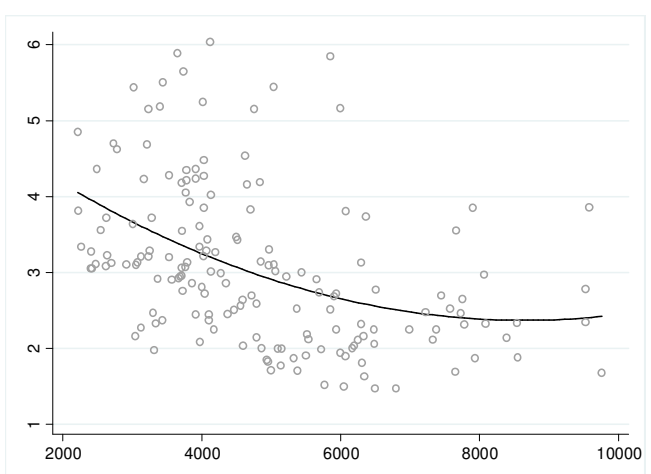

Panel d. Higher income countries

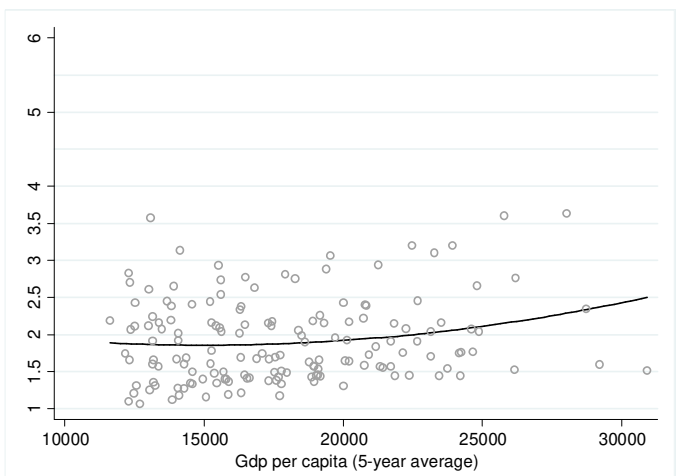


More importantly, average cross-period growth rates of the overall, extensive and intensive indicators of export concentration reported in Table 2 show that neither the MICs, whether in the MIT or not, nor the lower income countries did start concentrating their export during the period investigated in the present paper. Although the trend of diversification should be reversed and the number of different lines of production should drop if the developing country wants to reap aggregate productivity gains from the survival of the best fitted activities and firms (Hausman and Rodrik, 2003), only higher income countries could achieve positive variations of the overall concentration index in our sample. In contrast, countries in the MIT have barely started to rationalize their production and most of them are still diversifying their productive structure, notably on the extensive margins. This may explain why growth slows down there, as the output gains drawn from production and export diversification, notably along extensive margins, start to dissipate while the productivity gains drawn from concentration, along bot extensive and intensive margins, are still absent. Put differently, countries in the MIT are therefore not engaged in the phase of export concentration that is necessary to converge toward more developed economies, while they simultaneously exhibit a slower pace of diversification, other things set equal, than the LICs.

Table 2: Levels and cross-period growth rates of the overall, extensive margins and intensive margins concentration index: Middle Income Trap, Middle income not trapped, lower-income and higher-income countries

\begin{tabular}{ccccc}
\hline & MIT & MICs non-MIT & LICs & HICs \\
\hline Total concentration (level) & $3.07(1.04)$ & $2.85(.97)$ & $3.93(1.03)$ & $1.92(.56)$ \\
Extensive margins (level) & $.518(.41)$ & $.42(.35)$ & $.594(.568)$ & $.129(.155)$ \\
Intensive margins (level) & $2.55(.79)$ & $2.43(.77)$ & $3.33(1.02)$ & $1.80(.495)$ \\
Total concentration (variation in \%) & $-2.0(.79)$ & $-2.4(.089)$ & $-1.9(.086)$ & $+2.5(.079)$ \\
Extensive margins (variation in \%) & $-7.4(.10)$ & $-11.5(.33)$ & $+.5(.614)$ & $-16.9(1.66)$ \\
Intensive margins (variation in \%) & $+.02(.49)$ & $-.5(.10)$ & $+.12(.091)$ & $+2.8(.084)$ \\
\hline
\end{tabular}

Note: Standard error in parentheses; author's computations based on IMF indicators 
In Table 3, we investigate whether the pattern of productive transformation is different inside and outside of the MIT for both the restricted and extended reference samples. The different indicators of export concentration (overall, extensive margins and intensive margins concentration) are regressed on a set of drivers, with country and time fixed effects being included, and on the set of their interaction with the MIT dummy. The set of drivers is now standard in the literature on export diversification (Cadot et al., 2011b; Lectard and Rougier, 2018): the investment rate, the population growth rate, the skill ratio, the lagged level of GDP per capita and its squared value (in order to account for the hump shape Cadot et al. (2011a)), and trade openness ${ }^{\mathrm{xxiv}}$.

One essential difference between the MIT and the non-MIT comparison groups concerns the capacity of skills to trigger productive transformation through re-concentration. Whereas skills are crucial drivers of export concentration in the MICs not trapped, the skill ratio's impact on export concentration turns negative inside the MIT, as shown in columns 1 and 3. Moreover, this negative impact of skills on productive change inside the MIT is mainly driven by the dynamics of diversification along the extensive margins which is supported by skills inside the MIT, as can be seen in columns 3 and 4. From Table 3, we can infer that skills might be misused inside the MIT since, by feeding the pursuit of extensive diversification, they deliver lower growth dividend than if they were used to concentrate production on the most productive and competitive lines, as it is the case in MICs not trapped.

The fact that, inside the MIT, skills tends to support diversification of the extensive margins rather than concentration, of both extensive and intensive margins, points to the absence of a 
productivity-increasing rationalization of production in the MICs trapped. This may be another way to identify the issue of skill misallocation in the MIT.

Table 3: Drivers of productive transformation: Overall, intensive and extensive margins diversification, restricted, extended high and extended reference samples

\begin{tabular}{|c|c|c|c|c|c|c|}
\hline \multirow{3}{*}{ Dependent : } & $(1)$ & (2) & (3) & (4) & (5) & (6) \\
\hline & \multicolumn{2}{|c|}{ Concentration index (Theil) } & \multicolumn{2}{|c|}{ Extensive margins concentration } & \multicolumn{2}{|c|}{ Intensive margins concentration } \\
\hline & FE restricted & FE extended & FE restricted & FE extended & FE restricted & FE extended \\
\hline \multirow[t]{2}{*}{ MIT dummy } & $0.950 *$ & 0.007 & $0.620 * * *$ & $0.264^{*}$ & 0.334 & -0.266 \\
\hline & $(0.554)$ & $(0.551)$ & $(0.202)$ & $(0.154)$ & $(0.577)$ & $(0.505)$ \\
\hline \multirow[t]{2}{*}{ Lagged GDP per capita } & $-0.00036 * * *$ & $-1.39 \mathrm{e}-05$ & $-0.00015^{* *}$ & $8.10 \mathrm{e}-07$ & $-0.00021 *$ & $-1.42 \mathrm{e}-05$ \\
\hline & $(0.000115)$ & $(4.07 \mathrm{e}-05)$ & $(6.75 e-05)$ & $(1.83 \mathrm{e}-05)$ & $(0.000108)$ & $(3.77 \mathrm{e}-05)$ \\
\hline \multirow[t]{2}{*}{ Lag. GDP p.c. squared } & $2.35 \mathrm{e}-08^{* * *}$ & $2.20 \mathrm{e}-09^{*}$ & $1.27 \mathrm{e}-08 * * *$ & $8.96 \mathrm{e}-10 *$ & $1.08 \mathrm{e}-08$ & $1.28 \mathrm{e}-09$ \\
\hline & $(7.76 \mathrm{e}-09)$ & $(1.13 e-09)$ & $(4.11 \mathrm{e}-09)$ & $(4.80 \mathrm{e}-10)$ & $(7.37 \mathrm{e}-09)$ & $(9.73 \mathrm{e}-10)$ \\
\hline \multirow[t]{2}{*}{ Skill ratio } & $0.704 * *$ & 0.015 & $0.278 * *$ & 0.002 & 0.426 & 0.014 \\
\hline & $(0.318)$ & $(0.030)$ & $(0.106)$ & $(0.009)$ & $(0.333)$ & $(0.029)$ \\
\hline \multirow[t]{2}{*}{ MIT*skill ratio } & $-0.912 * * *$ & $-0.279 * *$ & $-0.399 * * *$ & $-0.158 * *$ & -0.512 & -0.120 \\
\hline & $(0.327)$ & $(0.124)$ & $(0.128)$ & $(0.075)$ & $(0.344)$ & $(0.139)$ \\
\hline \multirow[t]{2}{*}{ Trade openness } & $0.008^{* *}$ & 0.0008 & 0.0004 & -0.0005 & $0.008 * *$ & 0.0012 \\
\hline & $(0.0036)$ & $(0.0019)$ & $(0.0019)$ & $(0.0006)$ & $(0.0037)$ & $(0.002)$ \\
\hline \multirow[t]{2}{*}{ MIT*trade openness } & -0.0038 & 0.0015 & -0.0003 & 0.0003 & -0.0036 & 0.0012 \\
\hline & $(0.0032)$ & $(0.0031)$ & $(0.0018)$ & $(0.0012)$ & $(0.0037)$ & $(0.003)$ \\
\hline \multirow[t]{2}{*}{ Investment rate } & 0.0026 & -0.0058 & -0.0071 & -0.0066 & 0.0098 & 0.0006 \\
\hline & $(0.0087)$ & $(0.009)$ & $(0.0064)$ & $(0.004)$ & $(0.0106)$ & $(0.0093)$ \\
\hline \multirow[t]{2}{*}{ MIT*investment rate } & -0.012 & 0.006 & 0.0016 & 0.0045 & -0.014 & 0.0014 \\
\hline & $(0.012)$ & $(0.013)$ & $(0.008)$ & $(0.006)$ & $(0.012)$ & $(0.012)$ \\
\hline \multirow[t]{2}{*}{ Population growth } & -0.004 & 0.078 & 0.082 & 0.043 & -0.086 & 0.032 \\
\hline & $(0.074)$ & $(0.063)$ & $(0.070)$ & $(0.030)$ & $(0.080)$ & $(0.063)$ \\
\hline \multirow[t]{2}{*}{ MIT*population growth } & -0.009 & -0.050 & -0.117 & -0.067 & 0.107 & 0.019 \\
\hline & $(0.079)$ & $(0.089)$ & $(0.085)$ & $(0.051)$ & $(0.099)$ & $(0.092)$ \\
\hline \multirow[t]{2}{*}{ Constant } & $3.458 * * *$ & $2.648 * * *$ & $0.801 * * *$ & $0.483^{* * * *}$ & $2.657 * * *$ & $2.183^{* * *}$ \\
\hline & $(0.384)$ & $(0.330)$ & $(0.214)$ & $(0.104)$ & $(0.407)$ & $(0.350)$ \\
\hline Observations & 256 & 404 & 256 & 402 & 256 & 402 \\
\hline Number of countries & 48 & 64 & 48 & 64 & 48 & 64 \\
\hline Adj. R-squared & 0.37 & 0.24 & 0.46 & 0.3 & 0.16 & 0.11 \\
\hline Country FE & YES & YES & YES & YES & YES & YES \\
\hline Time FE & YES & YES & YES & YES & YES & YES \\
\hline
\end{tabular}

Robust standard errors in parentheses; Restricted means that the comparison group is limited to MICs not in the MIT; Extended means that $* * * \mathrm{p}<.01, * * \mathrm{p}<.05, * \mathrm{p}<.10, \mathrm{NS} \mathrm{p}>.10$

The next stage consists in checking if this contrasted pattern of export concentration effectively helps explain the difference of medium-run growth rate inside and outside the MIT. Table 4 displays estimations of equation 1 when the different dimensions of the productive diversification (overall export concentration, concentration along the intensive and 
extensive margins) are interacted with the MIT dummy. Columns 1 in Tables 4 and A4 first show respectively that while it has no impact in the group of MICs not trapped, a more concentrated set of exports slightly increases GDP growth in the reference group extended to higher income countries. The non-significant coefficient of the interaction term in the two columns indicates that the impact is not significantly different for the countries in the MIT, whatever the comparison subsample.

Table 4: GDP growth and export concentration: Restricted sample, contemporaneous and lagged models

\begin{tabular}{|c|c|c|c|c|c|c|}
\hline $\begin{array}{l}\text { Dependent : } \\
\text { 5-year GDP growth }\end{array}$ & $\begin{array}{c}(1) \\
\text { Simult. }\end{array}$ & $\begin{array}{c}(2) \\
\text { Lagged }\end{array}$ & $\begin{array}{l}\text { (3) } \\
\text { Simult. }\end{array}$ & $\begin{array}{c}(4) \\
\text { Lagged }\end{array}$ & $\begin{array}{c}(5) \\
\text { Simult. }\end{array}$ & $\begin{array}{c}(6) \\
\text { Lagged }\end{array}$ \\
\hline Lagged gdp per capita & $\begin{array}{c}-1.2 \mathrm{e}-05^{* * * *} \\
(1.9 \mathrm{e}-06)\end{array}$ & $\begin{array}{l}-7.5 \mathrm{e}-06 * * * \\
(1.9 \mathrm{e}-06)\end{array}$ & $\begin{array}{c}-1.2 \mathrm{e}-05^{* * *} \\
(1.7 \mathrm{e}-06)\end{array}$ & $\begin{array}{c}-8.1 \mathrm{e}-06 * * * \\
(1.8 \mathrm{e}-06)\end{array}$ & $\begin{array}{l}-1.2 \mathrm{e}-05 * * * \\
(1.9 \mathrm{e}-06)\end{array}$ & $\begin{array}{c}-7.1 \mathrm{e}-06 * * * \\
(2.0 \mathrm{e}-06)\end{array}$ \\
\hline Investment rate & $\begin{array}{c}0.0019 * * * \\
(0.0003)\end{array}$ & $\begin{array}{c}-0.0011 * * * \\
(0.0004)\end{array}$ & $\begin{array}{c}0.0019^{* * *} \\
(0.0004)\end{array}$ & $\begin{array}{c}-0.0010^{* *} \\
(0.0004)\end{array}$ & $\begin{array}{c}0.0019 * * * \\
(0.0004)\end{array}$ & $\begin{array}{c}-0.0011 * * \\
(0.0004)\end{array}$ \\
\hline Skill ratio & $\begin{array}{c}0.0055 \\
(0.0087)\end{array}$ & $\begin{array}{c}0.0050 \\
(0.0059)\end{array}$ & $\begin{array}{c}0.0045 \\
(0.0083)\end{array}$ & $\begin{array}{l}0.0056 \\
(0.0058)\end{array}$ & $\begin{array}{c}0.0063 \\
(0.0085)\end{array}$ & $\begin{array}{l}0.0056 \\
(0.0059)\end{array}$ \\
\hline Trade openess & $\begin{array}{c}0.0003 * * * \\
(8.9 \mathrm{e}-05)\end{array}$ & $\begin{array}{c}1.2 \mathrm{e}-05 \\
(8.7 \mathrm{e}-05)\end{array}$ & $\begin{array}{c}2.7 \mathrm{e}-04 * * * \\
(8.6 \mathrm{e}-05)\end{array}$ & $\begin{array}{l}-3.4 \mathrm{e}-06 \\
(8.3 \mathrm{e}-05)\end{array}$ & $\begin{array}{c}2.8 \mathrm{e}-04 * * * \\
(9.2 \mathrm{e}-05)\end{array}$ & $\begin{array}{l}2.5 \mathrm{e}-05 \\
(8.9 \mathrm{e}-05)\end{array}$ \\
\hline Population growth & $\begin{array}{c}-0.0092 * * \\
(0.0035)\end{array}$ & $\begin{array}{l}0.0008 \\
(0.0036)\end{array}$ & $\begin{array}{c}-0.0093 * * * \\
(0.0035)\end{array}$ & $\begin{array}{l}-0.0003 \\
(0.0036)\end{array}$ & $\begin{array}{c}-0.0095 * * * \\
(0.0034)\end{array}$ & $\begin{array}{c}0.0006 \\
(0.0037)\end{array}$ \\
\hline MIT dummy & $\begin{array}{l}-0.0171 \\
(0.0140)\end{array}$ & $\begin{array}{c}0.0304 \\
(0.0201)\end{array}$ & $\begin{array}{c}-0.0170^{* * * *} \\
(0.0049)\end{array}$ & $\begin{array}{l}-0.0075 \\
(0.0090)\end{array}$ & $\begin{array}{c}-0.0387 * * \\
(0.0162)\end{array}$ & $\begin{array}{c}0.0145 \\
(0.0192)\end{array}$ \\
\hline Export concentration & $\begin{array}{l}-0.0036 \\
(0.0037)\end{array}$ & $\begin{array}{c}0.0051 \\
(0.0041)\end{array}$ & $\begin{array}{l}- \\
-\end{array}$ & $\begin{array}{l}- \\
-\end{array}$ & $\begin{array}{l}- \\
-\end{array}$ & $\begin{array}{l}- \\
-\end{array}$ \\
\hline MIT*Concentration & $\begin{array}{l}-0.0017 \\
(0.0038)\end{array}$ & $\begin{array}{c}-0.0143 * * * \\
(0.0051)\end{array}$ & $\begin{array}{l}- \\
-\end{array}$ & $\begin{array}{l}- \\
-\end{array}$ & $\begin{array}{l}- \\
-\end{array}$ & $\begin{array}{l}- \\
-\end{array}$ \\
\hline Extensive margins & $\begin{array}{l}- \\
-\end{array}$ & $\begin{array}{l}- \\
-\end{array}$ & $\begin{array}{c}0.0102 \\
(0.0077)\end{array}$ & $\begin{array}{c}0.0080 \\
(0.0066)\end{array}$ & $\begin{array}{l}- \\
-\end{array}$ & $\begin{array}{l}- \\
-\end{array}$ \\
\hline MIT*Extensive margins & - & - & $\begin{array}{c}-0.0205^{* *} \\
(0.0086)\end{array}$ & $\begin{array}{c}-0.0215^{* * *} \\
(0.0071)\end{array}$ & - & - \\
\hline Intensive margins & - & - & - & - & $\begin{array}{l}-0.0062 \\
(0.0041)\end{array}$ & $\begin{array}{c}0.0032 \\
(0.0046)\end{array}$ \\
\hline MIT*Intensive margins & - & - & - & $\begin{array}{l}- \\
-\end{array}$ & $\begin{array}{c}0.0042 \\
(0.0041)\end{array}$ & $\begin{array}{l}-0.0117 * \\
(0.0062)\end{array}$ \\
\hline Constant & $\begin{array}{c}0.0491 * * * \\
(0.0165) \\
\end{array}$ & $\begin{array}{c}0.0609 * * * \\
(0.0137) \\
\end{array}$ & $\begin{array}{r}0.0368 * * \\
(0.0147) \\
\end{array}$ & $\begin{array}{c}0.0757 * * * \\
(0.0116) \\
\end{array}$ & $\begin{array}{c}0.0552^{* * * *} \\
(0.0141) \\
\end{array}$ & $\begin{array}{c}0.0682 * * * \\
(0.0128) \\
\end{array}$ \\
\hline Observations & 256 & 250 & 256 & 250 & 256 & 250 \\
\hline Number of idcountry & 48 & 48 & 48 & 48 & 48 & 48 \\
\hline Adjusted R-squared & 0.4531 & 0.3996 & 0.4593 & 0.3879 & 0.4531 & 0.3860 \\
\hline Country FE & YES & YES & YES & YES & YES & YES \\
\hline Time FE & YES & YES & YES & YES & YES & YES \\
\hline
\end{tabular}

Robust standard errors in parentheses; Restricted means that the comparison group is limited to MICs not in the MIT; *** $\mathrm{p}<.01, * * \mathrm{p}<.05$, * $\mathrm{p}<.10, \mathrm{NS} \mathrm{p}>.10$ 
When time lags are introduced, however, export concentration does hamper growth for the countries in the MIT, while the positive impact identified outside the trap is less significant (only at $12 \%$ of risk), whatever the reference group (columns 2 in Tables 4 and A4). Based on the lagged model estimation on the restricted sample of column 2, a one standard deviation increase of the overall concentration index leads to a .45 standard deviation decrease (1.1 percentage point) of the average GDP growth rate inside the MIT. By contrast, a one standard deviation increase of the concentration index leads to .3 standard deviation (.7 percentage point) expansion of the GDP growth rate in the MICs non-trapped and HICs (based on estimations of Table A4's column 1).

The adverse growth impact of overall concentration is confirmed as far as extensive and intensive margins are considered. As for extensive margins concentration, Tables 4 and A4's columns 3 and 4 show that it tends to reduce growth inside the MIT while triggering growth in the non-trapped countries of the extended subsample and having a positive impact, albeit not significant, in other middle income countries. The adverse impact inside the MIT is measured for both the contemporaneous and the lagged models on the restricted sample (columns 3 and 4, Table 4). Magnitudes of impact are significant as one standard deviation increase of export concentration along the extensive margins leads to .8 percentage point decrease (corresponding to .33 standard deviation decrease) of the average GDP growth rate for the countries in the MIT, while it leads to .6 percentage point increase (corresponding to .27 standard deviation decrease) for the HICs and the MICs not trapped (computations based on Tables 4's columns 3 and 4). The impact is fairly close when based on computations of the lagged model. Column 6 of Table 4 shows that concentration along the intensive margins also tends to reduce growth rates inside the MIT notably in the restricted subsample. Magnitudes of impact are similar to extensive margins since, based on the latter model's estimation, a one 
standard deviation increase of the index of concentration along the intensive margins causes a .36 standard deviation decrease (corresponding to a .9 percentage point decrease) of the fiveyear GDP growth rate in the MIT, while it has no growth impact outside the MIT.

Table 4 and A4's results thus suggest that more concentrated exports tend to slow down medium-run GDP growth inside the MIT, while having no or slightly positive impact outside the trap. This contradictory growth impact inside and outside the trap may be explained by the different nature of export concentration in the two groups of countries.

First, our data show that, inside the MIT, productive transformation is essentially driven by productive diversification on both the extensive and intensive margins rather than on reconcentration. This pattern of productive change favors extensive growth, as the productivityenhancing selection of firms and products has not started or has not delivered its effects. At intermediate level of income, structural change should increasingly rely on intra-industry factor mobility, through selection and survival of the most competitive firms (Melitz, 2003; UNIDO, 2010b). For MICs in the MIT, transition to higher income levels would therefore require that the least productive sectors and firms are progressively replaced by more productive ones.

Second, as explained above, export concentration inside the MIT does not necessarily spur aggregate productive efficiency in the same way as it does so in higher income countries. In MICs, export concentration may notably be prompted by low export survival rate consecutive to greater competitive pressure on inefficient domestic firms, as was put forward by Nicita et al. (2013). Lastly, these results point to the scissor effect, MICs inside the trap finding it hard to compete with higher income countries' exports as a consequence of their failure to modify substantially their productive structure, while the competitiveness on exports corresponding to 
their initial specialization has simultaneously vanished, notably to the benefit of poorer economies. Testing this more precisely on trade data would be useful.

\section{Conclusion: What difference do better policies (related to productive change) shall make?}

In this paper we test the assumption that middle income countries undergoing sustained growth slowdowns do face specific structural difficulties to upgrade their productive capabilities and efficiently use labor force and skills. What is the dominant explanation of MITs is certainly a matter of context and of cumulative causation (Han and Wei, 2017). However, based on a large panel of MICs, we find that, among the various drivers of the MIT that have been listed by the recent literature, those related to the productive structure, the extensive regime of economic growth, the pattern of productive use of skills and other inputs and the dynamics of productive change and diversification, help explain why some middle countries undergo persistent growth slowdowns.

More specifically, our estimations point to labor and skill misallocation as potential explanations for the slower pace of growth inside the MIT, this impact being potentially due to the dearth of productive jobs in the industry for a large share of young workers insufficiently skilled. Our estimations could also identify complex mechanisms underlying sustained growth slowdown episodes in the MIT that are not widely shared in the existing literature.

Our estimations point to the high relevance to middle income countries of policies supporting (i) the shift from the extensive to the intensive growth pattern, and (ii) the move from extensive to intensive margins. Additional empirical analyses are nevertheless required in order to more precisely identify the underlying mechanisms pointed by our estimations in each specific context. A more fine-grained analysis of the sectoral productivity gaps and input 
use across countries trapped and non-trapped would notably be useful. Further empirical investigation of the complementary effects of productive and institutional structures would also certainly help identifying and understanding the crucial policy trade-offs faced by middle-income countries. 


\section{Appendix}

Table A1: GDP growth drivers, capital and population growth: Fixed Effect estimations of the contemporaneous and lagged models on the extended sample

\begin{tabular}{|c|c|c|c|c|c|c|c|c|}
\hline $\begin{array}{l}\text { Dependent : } \\
\text { 5-year av. GDP } \\
\text { growth }\end{array}$ & Contemp. & $\begin{array}{c}(2) \\
\text { Lagged }\end{array}$ & Contempor. & Lagged & Contempor. & Lagged & Contempor. & Lagged \\
\hline L. GDP p. cap. & $\begin{array}{c}-5.7 \mathrm{e}-06 * * * \\
(7.0 \mathrm{e}-07)\end{array}$ & $\begin{array}{l}-0.0019 \\
(0.0024)\end{array}$ & $\begin{array}{c}-5.8 \mathrm{e}-06 * * * \\
(6.6 \mathrm{e}-07)\end{array}$ & $\begin{array}{c}-0.008 * * * \\
(0.002)\end{array}$ & $\begin{array}{c}-5.4 \mathrm{e}-06^{* * * *} \\
(6.8 \mathrm{e}-07)\end{array}$ & $\begin{array}{l}0.0007 \\
(0.002)\end{array}$ & $\begin{array}{c}-5.9 \mathrm{e}-06 * * * \\
(6.9 \mathrm{e}-07)\end{array}$ & $\begin{array}{c}-4.9 \mathrm{e}- \\
06 * * * \\
(4.2 \mathrm{e}-07)\end{array}$ \\
\hline Population growth & $\begin{array}{c}-0.001 \\
(0.0031)\end{array}$ & $\begin{array}{l}0.004 * * \\
(0.002)\end{array}$ & $\begin{array}{l}-0.0012 \\
(0.0031)\end{array}$ & $\begin{array}{l}0.007 * * \\
(0.003)\end{array}$ & $\begin{array}{c}0.0024 \\
(0.0024)\end{array}$ & $\begin{array}{l}0.004 * * \\
(0.002)\end{array}$ & $\begin{array}{l}- \\
-\end{array}$ & $\begin{array}{l}- \\
-\end{array}$ \\
\hline Skill ratio & $\begin{array}{l}0.004 * * \\
(0.0017)\end{array}$ & $\begin{array}{l}7.4 \mathrm{e}-05^{*} \\
(4.1 \mathrm{e}-05)\end{array}$ & $\begin{array}{c}0.0036^{* *} \\
(0.0015)\end{array}$ & $\begin{array}{l}1.1 \mathrm{e}-04 * * \\
(4.8 \mathrm{e}-05)\end{array}$ & $\begin{array}{c}0.0037 * * \\
(0.0017)\end{array}$ & $\begin{array}{c}8.0 \mathrm{e}-05^{* *} \\
(3.9 \mathrm{e}-05)\end{array}$ & $\begin{array}{c}0.0035 * * \\
(0.0017)\end{array}$ & $\begin{array}{c}0.004 * * \\
(0.002)\end{array}$ \\
\hline Trade openness & $\begin{array}{c}1.7 \mathrm{e}-04 * * * \\
(5.9 \mathrm{e}-05)\end{array}$ & $\begin{array}{c}-5.3 \mathrm{e}-06^{* * *} \\
(4.5 \mathrm{e}-07)\end{array}$ & $\begin{array}{c}2.0 \mathrm{e}-04 * * * \\
(5.6 \mathrm{e}-05)\end{array}$ & $\begin{array}{c}-3.2 \mathrm{e}-06 * * * \\
(3.7 \mathrm{e}-07)\end{array}$ & $\begin{array}{c}1.7 \mathrm{e}-04 * * * \\
(5.5 \mathrm{e}-05)\end{array}$ & $\begin{array}{c}-5.1 \mathrm{e}-06 * * * \\
(4.0 \mathrm{e}-07)\end{array}$ & $\begin{array}{c}1.7 \mathrm{e}-04 * * * \\
(5.6 \mathrm{e}-05)\end{array}$ & $\begin{array}{c}7.1 \mathrm{e}-05^{*} \\
(3.9 \mathrm{e}-05) \\
-\end{array}$ \\
\hline Investment rate & $\begin{array}{c}0.0014 * * * \\
(0.0003)\end{array}$ & $\begin{array}{c}-0.0014 * * * \\
(0.0003)\end{array}$ & $\begin{array}{c}0.0008 * * \\
(0.0004)\end{array}$ & $\begin{array}{c}-0.0017 * * * \\
(0.0004)\end{array}$ & $\begin{array}{c}0.0014 * * * \\
(0.0003)\end{array}$ & $\begin{array}{c}-0.0014 * * * \\
(0.0003)\end{array}$ & $\begin{array}{c}0.0014 * * * \\
(0.0003)\end{array}$ & $\begin{array}{c}0.0015 * * * \\
(0.0003)\end{array}$ \\
\hline MIT dummy & $\begin{array}{c}-0.023 * * * \\
(0.007)\end{array}$ & $\begin{array}{c}-0.022 * * * \\
(0.007)\end{array}$ & $\begin{array}{c}-0.055^{* * * *} \\
(0.016)\end{array}$ & $\begin{array}{c}0.004 \\
(0.013)\end{array}$ & $\begin{array}{l}-0.005 \\
(0.009)\end{array}$ & $\begin{array}{l}-0.006 \\
(0.010)\end{array}$ & $\begin{array}{l}-0.012 \\
(0.016)\end{array}$ & $\begin{array}{c}0.011 \\
(0.014)\end{array}$ \\
\hline MIT*Investment rate & $\begin{array}{l}- \\
-\end{array}$ & $\begin{array}{l}- \\
-\end{array}$ & $\begin{array}{c}0.0012 * * \\
(0.0006)\end{array}$ & $\begin{array}{l}-0.0007 \\
(0.0006)\end{array}$ & $\begin{array}{l}- \\
-\end{array}$ & $\begin{array}{l}- \\
-\end{array}$ & $\begin{array}{l}- \\
-\end{array}$ & $\begin{array}{l}- \\
-\end{array}$ \\
\hline MIT*Population gr. & $\begin{array}{l}- \\
-\end{array}$ & $\begin{array}{l}- \\
-\end{array}$ & $\begin{array}{l}- \\
-\end{array}$ & $\begin{array}{l}- \\
-\end{array}$ & $\begin{array}{c}-0.0095^{* *} \\
(0.004)\end{array}$ & $\begin{array}{c}-0.0071 * \\
(0.004)\end{array}$ & $\begin{array}{l}- \\
-\end{array}$ & $\begin{array}{l}- \\
-\end{array}$ \\
\hline Dependency rate & $\begin{array}{l}- \\
-\end{array}$ & $\begin{array}{l}- \\
-\end{array}$ & $\begin{array}{l}- \\
-\end{array}$ & $\begin{array}{l}- \\
-\end{array}$ & $\begin{array}{l}- \\
-\end{array}$ & $\begin{array}{l}- \\
-\end{array}$ & $\begin{array}{c}3.34 \mathrm{e}-04 \\
(2.30 \mathrm{e}-04)\end{array}$ & $\begin{array}{c}6.31 \mathrm{e}-05 \\
(2.02 \mathrm{e}-04) \\
-4.55 \mathrm{e}-\end{array}$ \\
\hline MIT*Dependency & $\begin{array}{l}- \\
-\end{array}$ & $\begin{array}{l}- \\
-\end{array}$ & $\begin{array}{l}- \\
-\end{array}$ & - & $\begin{array}{l}- \\
-\end{array}$ & - & $\begin{array}{l}-1.70 \mathrm{e}-04 \\
(2.37 \mathrm{e}-04)\end{array}$ & $\begin{array}{c}04 * * \\
(2.06 \mathrm{e}-04)\end{array}$ \\
\hline Constant & $\begin{array}{c}0.026 * * * \\
(0.008)\end{array}$ & $\begin{array}{c}0.095 * * * \\
(0.007)\end{array}$ & $\begin{array}{c}0.042 * * * \\
(0.011)\end{array}$ & $\begin{array}{c}0.093 * * * \\
(0.010)\end{array}$ & $\begin{array}{l}0.018^{*} \\
(0.009)\end{array}$ & $\begin{array}{c}0.088 * * * \\
(0.008)\end{array}$ & $\begin{array}{c}0.005 \\
(0.016)\end{array}$ & $\begin{array}{c}0.086 * * * \\
(0.015)\end{array}$ \\
\hline Obs. & 411 & 405 & 411 & 405 & 411 & 405 & 411 & 405 \\
\hline Number of groups & 65 & 65 & 65 & 65 & 65 & 65 & 65 & 65 \\
\hline Adj. R-squared & 0.34 & 0.37 & 0.35 & 0.26 & 0.35 & 0.38 & 0.34 & 0.38 \\
\hline Country FE & YES & YES & YES & YES & YES & YES & YES & YES \\
\hline Time FE & YES & YES & YES & YES & YES & YES & YES & YES \\
\hline $\begin{array}{r}\text { Marg. impact (at } \\
\text { means) }\end{array}$ & & & \multicolumn{2}{|c|}{$\mathrm{X}_{1}=$ Investment } & \multicolumn{2}{|c|}{$\mathrm{X}_{1}=$ Population gr. } & \multicolumn{2}{|c|}{$\mathrm{X}_{1}=$ Dependency } \\
\hline $\begin{array}{r}\text { MIT: } X_{1} \\
\text { non-MIT: } X_{1}\end{array}$ & $\begin{array}{l}- \\
-\end{array}$ & $\begin{array}{l}- \\
- \\
\end{array}$ & $\begin{array}{r}+.39 \\
+.17 \\
\end{array}$ & $\begin{array}{l}-.33 \\
-.37 \\
\end{array}$ & $\begin{array}{l}-.40 \\
\mathrm{NS}\end{array}$ & $\begin{array}{r}-.13 \\
+.16 \\
\end{array}$ & $\begin{array}{l}\text { NS } \\
\text { NS }\end{array}$ & $\begin{array}{l}-.34 \\
\text { NS }\end{array}$ \\
\hline
\end{tabular}

Robust standard errors in parentheses; Restricted means that the comparison group is limited to MICs not in the MIT; Extended means that the restricted comparison group is extended to HICs; ${ }^{\text {a) }}$ the marginal impact of the variable X interacted with the MIT dummy in the corresponding column measures the variation of the GDP growth rate (in terms of standard deviation) for a one standard deviation increase of X (at the mean value of all other regressors); in bold are reported the marginal impacts that are statistically different for the MIT and non-MIT samples ; *** $\mathrm{p}<.01, * * \mathrm{p}<.05, * \mathrm{p}<.10, \mathrm{NS} \mathrm{p}>.10$ 
Table A2: GDP growth drivers: human capital, contemporaneous and lagged models, restricted sample

\begin{tabular}{|c|c|c|c|c|c|c|}
\hline $\begin{array}{l}\text { Dependent : } \\
\text { 5-year av. GDP } \\
\text { growth }\end{array}$ & $\begin{array}{c}\text { (1) } \\
\text { Simult. }\end{array}$ & Lagged & $\begin{array}{c}\text { (3) } \\
\text { Simult. }\end{array}$ & Lagged & Simult. & $\begin{array}{c}\text { (6) } \\
\text { Lagged }\end{array}$ \\
\hline Population growth & $\begin{array}{c}-0.008 * * \\
(0.004)\end{array}$ & $\begin{array}{c}0.001 \\
(0.004)\end{array}$ & $\begin{array}{c}-0.008 * * \\
(0.004)\end{array}$ & $\begin{array}{c}0.000 \\
(0.004)\end{array}$ & $\begin{array}{c}-0.008 * * \\
(0.004)\end{array}$ & $\begin{array}{c}0.001 \\
(0.004)\end{array}$ \\
\hline Trade openness & $\begin{array}{c}3.0 \mathrm{e}-04 * * * \\
(9.45 \mathrm{e}-05)\end{array}$ & $\begin{array}{l}-0.001 * * \\
(4.3 \mathrm{e}-04)\end{array}$ & $\begin{array}{l}3.2 \mathrm{e}-04 * * * \\
(9.31 \mathrm{e}-05)\end{array}$ & $\begin{array}{c}-9.3 e-04 * * \\
(4.3 e-04)\end{array}$ & $\begin{array}{c}3.0 \mathrm{e}-04 * * * \\
(9.36 \mathrm{e}-05)\end{array}$ & $\begin{array}{l}-0.001 * * \\
(4.3 e-04)\end{array}$ \\
\hline $\begin{array}{l}\text { Lagged GDP per } \\
\text { capita }\end{array}$ & $\begin{array}{c}-1.2 \mathrm{e}-05 * * * \\
(1.88 \mathrm{e}-06)\end{array}$ & $\begin{array}{c}5.2 \mathrm{e}-05 \\
(8.4 \mathrm{e}-05)\end{array}$ & $\begin{array}{c}-1.3 \mathrm{e}-05 * * * \\
(1.88 \mathrm{e}-06)\end{array}$ & $\begin{array}{c}5.3 e-05 \\
(8.3 e-05)\end{array}$ & $\begin{array}{c}-1.3 \mathrm{e}-05 * * * \\
(1.88 \mathrm{e}-06)\end{array}$ & $\begin{array}{c}4.1 \mathrm{e}-05 \\
(8.4 \mathrm{e}-05)\end{array}$ \\
\hline Investment rate & $\begin{array}{c}0.002 * * * \\
(0.000)\end{array}$ & $\begin{array}{c}-8.2 \mathrm{e}-06 * * * \\
(1.9 \mathrm{e}-06)\end{array}$ & $\begin{array}{c}0.002 * * * \\
(0.000)\end{array}$ & $\begin{array}{c}-8.4 \mathrm{e}-06 * * * \\
(1.9 \mathrm{e}-06)\end{array}$ & $\begin{array}{c}0.002 * * * \\
(0.000)\end{array}$ & $\begin{array}{c}-7.9 \mathrm{e}-06 * * * \\
(1.9 \mathrm{e}-06)\end{array}$ \\
\hline MIT dummy & $\begin{array}{c}-0.022 * * * \\
(0.006)\end{array}$ & $\begin{array}{c}-0.024 * * \\
(0.010)\end{array}$ & $\begin{array}{c}-0.019 * * \\
(0.008)\end{array}$ & $\begin{array}{c}-0.019 * * \\
(0.008)\end{array}$ & $\begin{array}{c}-0.023 * * * \\
(0.006)\end{array}$ & $\begin{array}{c}-0.022 * * \\
(0.008)\end{array}$ \\
\hline Skill ratio & $\begin{array}{c}0.014 \\
(0.020)\end{array}$ & $\begin{array}{l}-0.004 \\
(0.015)\end{array}$ & - & - & - & - \\
\hline MIT*Skill ratio & $\begin{array}{l}-0.012 \\
(0.022)\end{array}$ & $\begin{array}{c}0.015 \\
(0.017)\end{array}$ & - & - & - & - \\
\hline $\begin{array}{l}\text { Secondary } \\
\text { schooling }\end{array}$ & - & - & $\begin{array}{c}1.0 \mathrm{e}-04 \\
(4.1 \mathrm{e}-04)\end{array}$ & $\begin{array}{c}1.1 \mathrm{e}-04 \\
(4.6 \mathrm{e}-04)\end{array}$ & - & - \\
\hline $\begin{array}{l}\text { MIT*Secondary } \\
\text { school. }\end{array}$ & - & - & $\begin{array}{l}-3.2 \mathrm{e}-04 \\
(4.1 \mathrm{e}-04)\end{array}$ & $\begin{array}{l}-1.5 \mathrm{e}-04 \\
(4.6 \mathrm{e}-04)\end{array}$ & - & - \\
\hline Tertiary schooling & - & - & - & - & $\begin{array}{l}3.1 \mathrm{e}-04 \\
(0.001)\end{array}$ & $\begin{array}{c}4.2 \mathrm{e}-04 \\
(8.1 \mathrm{e}-04)\end{array}$ \\
\hline $\begin{array}{l}\text { MIT*Tertiary } \\
\text { school. }\end{array}$ & - & - & - & - & $\begin{array}{l}-0.001 \\
(0.001)\end{array}$ & $\begin{array}{c}0.001 \\
(0.001)\end{array}$ \\
\hline Constant & $\begin{array}{c}0.033 * * \\
(0.014)\end{array}$ & $\begin{array}{c}0.079 * * * \\
(0.012)\end{array}$ & $\begin{array}{c}0.037 * * * \\
(0.013)\end{array}$ & $\begin{array}{c}0.077 * * * \\
(0.012)\end{array}$ & $\begin{array}{c}0.037 * * * \\
(0.012)\end{array}$ & $\begin{array}{c}0.077 * * * \\
(0.011)\end{array}$ \\
\hline Observations & 261 & 255 & 261 & 255 & 261 & 255 \\
\hline No of groups & 49 & 49 & 49 & 49 & 49 & 49 \\
\hline Adj. R-squared & 0.444 & 0.361 & 0.444 & 0.358 & 0.443 & 0.362 \\
\hline Country FE & YES & YES & YES & YES & YES & YES \\
\hline Time FE & YES & YES & YES & YES & YES & YES \\
\hline
\end{tabular}

Notes: Robust standard errors in parentheses; *** $\mathrm{p}<.01, * * \mathrm{p}<.05, * \mathrm{p}<.10$ 
Table A3: GDP growth drivers, human capital, simultaneous and lagged models, extended sample

\begin{tabular}{|c|c|c|c|c|c|c|}
\hline $\begin{array}{l}\text { Dependent: } \\
\text { 5-year av. GDP } \\
\text { growth }\end{array}$ & Simult. & Lagged & Simult. & Lagged & Simult. & Lagged \\
\hline Popul. growth & $\begin{array}{l}-0.001 \\
(0.003)\end{array}$ & $\begin{array}{l}-0.002 \\
(0.002)\end{array}$ & $\begin{array}{l}-0.001 \\
(0.003)\end{array}$ & $\begin{array}{l}-0.002 \\
(0.002)\end{array}$ & $\begin{array}{l}-0.002 \\
(0.003)\end{array}$ & $\begin{array}{l}-0.001 \\
(0.002)\end{array}$ \\
\hline Trade openness & $\begin{array}{c}1.7 \mathrm{e}-04 * * * \\
(5.94 \mathrm{e}-05)\end{array}$ & $\begin{array}{c}-0.0015 * * * \\
(2.9 \mathrm{e}-04)\end{array}$ & $\begin{array}{l}1.7 \mathrm{e}-04 * * * \\
(5.89 \mathrm{e}-05)\end{array}$ & $\begin{array}{c}-0.0014 * * * \\
(2.9 \mathrm{e}-04)\end{array}$ & $\begin{array}{c}1.8 \mathrm{e}-04 * * * \\
(5.98 \mathrm{e}-05)\end{array}$ & $\begin{array}{c}-0.0015^{* * *} \\
(3.0 \mathrm{e}-04)\end{array}$ \\
\hline L. GDP per capita & $\begin{array}{c}-5.7 \mathrm{e}-06 * * * \\
(7.01 \mathrm{e}-07)\end{array}$ & $\begin{array}{l}7.4 \mathrm{e}-05^{*} \\
(4.0 \mathrm{e}-05)\end{array}$ & $\begin{array}{c}-5.9 \mathrm{e}-06 * * * \\
(7.43 \mathrm{e}-07)\end{array}$ & $\begin{array}{c}7.0 e-05 \\
(4.3 e-05)\end{array}$ & $\begin{array}{c}-6.4 \mathrm{e}-06 * * * \\
(9.79 \mathrm{e}-07)\end{array}$ & $\begin{array}{l}7.5 \mathrm{e}-05^{*} \\
(4.2 \mathrm{e}-05)\end{array}$ \\
\hline Investment rate & $\begin{array}{c}0.001 * * * \\
(0.000)\end{array}$ & $\begin{array}{c}-5.2 \mathrm{e}-06 * * * \\
(4.4 \mathrm{e}-07)\end{array}$ & $\begin{array}{c}0.001 * * * \\
(0.000)\end{array}$ & $\begin{array}{c}-5.2 \mathrm{e}-06 * * * \\
(5.0 \mathrm{e}-07)\end{array}$ & $\begin{array}{c}0.001 * * * \\
(0.000)\end{array}$ & $\begin{array}{c}-5.3 \mathrm{e}-06 * * * \\
(4.6 \mathrm{e}-07)\end{array}$ \\
\hline MIT dummy & $\begin{array}{c}-0.023 * * * \\
(0.007)\end{array}$ & $\begin{array}{c}-0.024 * * * \\
(0.008)\end{array}$ & $\begin{array}{l}-0.015 \\
(0.010)\end{array}$ & $\begin{array}{c}-0.021 * * * \\
(0.007)\end{array}$ & $\begin{array}{c}-0.021 * * * \\
(0.006)\end{array}$ & $\begin{array}{c}-0.023 * * * \\
(0.007)\end{array}$ \\
\hline Skill ratio & $\begin{array}{c}0.004 * * \\
(0.002)\end{array}$ & $\begin{array}{l}0.003 * \\
(0.001)\end{array}$ & - & - & - & - \\
\hline MIT*Skill ratio & $\begin{array}{l}-0.001 \\
(0.008)\end{array}$ & $\begin{array}{c}0.009 \\
(0.007)\end{array}$ & - & - & - & - \\
\hline Secondary & - & - & $\begin{array}{l}-1.8 \mathrm{e}-04 \\
(2.0 \mathrm{e}-04)\end{array}$ & $\begin{array}{l}-3.6 \mathrm{e}-05 \\
(2.0 \mathrm{e}-04)\end{array}$ & - & - \\
\hline MIT*Secondary & - & - & $\begin{array}{l}-3.4 \mathrm{e}-04 \\
(3.3 \mathrm{e}-04)\end{array}$ & $\begin{array}{l}-4.2 \mathrm{e}-05 \\
(3.5 \mathrm{e}-04)\end{array}$ & - & - \\
\hline Tertiary & - & - & - & - & $\begin{array}{c}0.0014 * \\
(7.7 \mathrm{e}-04)\end{array}$ & $\begin{array}{l}8.9 \mathrm{e}-04 * \\
(4.8 \mathrm{e}-04)\end{array}$ \\
\hline MIT*Tertiary & - & - & - & - & $\begin{array}{l}-0.002 \\
(0.001)\end{array}$ & $\begin{array}{c}0.001 \\
(0.001)\end{array}$ \\
\hline Constant & $\begin{array}{c}0.026^{* * * *} \\
(0.008)\end{array}$ & $\begin{array}{c}0.095 * * * \\
(0.007)\end{array}$ & $\begin{array}{c}0.030 * * * \\
(0.008)\end{array}$ & $\begin{array}{c}0.095 * * * \\
(0.007) \\
\end{array}$ & $\begin{array}{c}0.028 * * * \\
(0.008)\end{array}$ & $\begin{array}{c}0.094 * * * \\
(0.007)\end{array}$ \\
\hline Observations & 411 & 405 & 411 & 405 & 411 & 405 \\
\hline No of groups & 65 & 65 & 65 & 65 & 65 & 65 \\
\hline Adj. R-squared & 0.338 & 0.373 & 0.340 & 0.370 & 0.346 & 0.378 \\
\hline Country FE & YES & YES & YES & YES & YES & YES \\
\hline Time FE & YES & YES & YES & YES & YES & YES \\
\hline
\end{tabular}

Note: Robust standard errors in parentheses; $* * * \mathrm{p}<.01, * * \mathrm{p}<.05, * \mathrm{p}<.10$. 
Table A4: GDP growth and productive diversification: Simultaneous and lagged models, extended sample

\begin{tabular}{|c|c|c|c|c|c|c|}
\hline $\begin{array}{l}\text { Dependent : } \\
\text { 5-year GDP growth }\end{array}$ & $\begin{array}{c}\text { (1) } \\
\text { Simult. }\end{array}$ & $\begin{array}{c}(2) \\
\text { Lagged }\end{array}$ & $\begin{array}{c}\text { (3) } \\
\text { Simult. }\end{array}$ & $\begin{array}{c}(4) \\
\text { Lagged }\end{array}$ & $\begin{array}{c}\text { (5) } \\
\text { Simult. }\end{array}$ & $\begin{array}{c}(6) \\
\text { Lagged }\end{array}$ \\
\hline L.GDP per capita & $\begin{array}{c}-5.89 \mathrm{e}-06 * * * \\
(6.98 \mathrm{e}-07)\end{array}$ & $\begin{array}{c}-5.38 \mathrm{e}-06 * * * \\
(4.96 \mathrm{e}-07)\end{array}$ & $\begin{array}{c}-5.65 \mathrm{e}-06 * * * \\
(6.78 \mathrm{e}-07)\end{array}$ & $\begin{array}{c}-5.30 \mathrm{e}-06 * * * \\
(4.58 \mathrm{e}-07)\end{array}$ & $\begin{array}{c}-5.73 \mathrm{e}-06 * * * \\
(7.29 \mathrm{e}-07)\end{array}$ & $\begin{array}{c}-5.23 \mathrm{e}-06 * * * \\
(4.76 \mathrm{e}-07)\end{array}$ \\
\hline Investment rate & $\begin{array}{c}0.0015^{* * * *} \\
(0.0003)\end{array}$ & $\begin{array}{c}-0.00146 * * * \\
(0.0003)\end{array}$ & $\begin{array}{c}0.0015 * * * \\
(0.0003)\end{array}$ & $\begin{array}{c}-0.00146 * * * \\
(0.0003)\end{array}$ & $\begin{array}{c}0.0015 * * * \\
(0.0003)\end{array}$ & $\begin{array}{c}-0.00142 * * * \\
(0.0003)\end{array}$ \\
\hline Skill ratio & $\begin{array}{c}0.0038 * * \\
(0.0017)\end{array}$ & $\begin{array}{c}0.0032 * * \\
(0.0016)\end{array}$ & $\begin{array}{c}0.0038 * * \\
(0.0017)\end{array}$ & $\begin{array}{c}0.0033 * * \\
(0.0015)\end{array}$ & $\begin{array}{c}0.0039 * * \\
(0.0017)\end{array}$ & $\begin{array}{c}0.0036 * * \\
(0.0016)\end{array}$ \\
\hline Trade openness & $\begin{array}{c}0.0001 * * * \\
(0.0001)\end{array}$ & $\begin{array}{c}0.0001 \\
(0.0000)\end{array}$ & $\begin{array}{l}0.0001 * * \\
(0.0001)\end{array}$ & $\begin{array}{c}0.0001 \\
(0.0000)\end{array}$ & $\begin{array}{l}0.0002 * * \\
(0.0001)\end{array}$ & $\begin{array}{c}0.0001 \\
(0.0000)\end{array}$ \\
\hline Population growth & $\begin{array}{l}-0.0026 \\
(0.0029)\end{array}$ & $\begin{array}{l}-0.0023 \\
(0.0021)\end{array}$ & $\begin{array}{l}-0.0024 \\
(0.0030)\end{array}$ & $\begin{array}{l}-0.0024 \\
(0.0022)\end{array}$ & $\begin{array}{l}-0.0024 \\
(0.0029)\end{array}$ & $\begin{array}{l}-0.0027 \\
(0.0021)\end{array}$ \\
\hline Concentration & $\begin{array}{c}0.0090 * * \\
(0.0038)\end{array}$ & $\begin{array}{c}0.0055 \\
(0.0035)\end{array}$ & & & & \\
\hline MIT dummy & $\begin{array}{l}-0.0064 \\
(0.0188)\end{array}$ & $\begin{array}{c}0.0232 \\
(0.0188)\end{array}$ & $\begin{array}{l}-0.0156 \\
(0.0174)\end{array}$ & $\begin{array}{c}0.0087 \\
(0.0183)\end{array}$ & $\begin{array}{c}-0.0207 * * \\
(0.0083)\end{array}$ & $\begin{array}{l}-0.0112 \\
(0.0075)\end{array}$ \\
\hline MIT*Concentration & $\begin{array}{l}-0.0048 \\
(0.0043)\end{array}$ & $\begin{array}{c}-0.0125^{* *} \\
(0.0050)\end{array}$ & & & & \\
\hline Extensive margins & & & $\begin{array}{l}0.0172 * * \\
(0.0086)\end{array}$ & $\begin{array}{c}0.0084 \\
(0.0059)\end{array}$ & & \\
\hline $\begin{array}{l}\text { MIT* Extensive } \\
\text { margins }\end{array}$ & & & $\begin{array}{l}-0.0152 \\
(0.0094)\end{array}$ & $\begin{array}{c}-0.0183 * * * \\
(0.0060)\end{array}$ & & \\
\hline Intensive margins & & & & & $\begin{array}{c}0.0063 \\
(0.0044)\end{array}$ & $\begin{array}{c}0.0034 \\
(0.0035)\end{array}$ \\
\hline $\begin{array}{l}\text { MIT }^{*} \text { Intensive } \\
\text { margins }\end{array}$ & & & & & $\begin{array}{l}-0.0020 \\
(0.0048)\end{array}$ & $\begin{array}{l}-0.0101 \\
(0.0064)\end{array}$ \\
\hline Constant & $\begin{array}{c}0.0045 \\
(0.0104)\end{array}$ & $\begin{array}{l}0.0815 * * * \\
(0.0093)\end{array}$ & $\begin{array}{c}0.0132 \\
(0.0104)\end{array}$ & $\begin{array}{c}0.0887 * * * \\
(0.0087)\end{array}$ & $\begin{array}{l}0.0215 * * \\
(0.0083)\end{array}$ & $\begin{array}{c}0.0925 * * * \\
(0.0067)\end{array}$ \\
\hline Observations & 404 & 399 & 402 & 395 & 402 & 395 \\
\hline $\begin{array}{l}\text { Number of } \\
\text { idcountry }\end{array}$ & 64 & 64 & 64 & 64 & 64 & 64 \\
\hline Adjusted R-squared & 0.3546 & 0.4026 & 0.3514 & 0.3936 & 0.3532 & 0.3949 \\
\hline Country FE & YES & YES & YES & YES & YES & YES \\
\hline Time FE & YES & YES & YES & YES & YES & YES \\
\hline
\end{tabular}

Note: Robust standard errors in parentheses; *** $\mathrm{p}<.01, * * \mathrm{p}<.05, * \mathrm{p}<.10, \mathrm{NS}$. 
Table A5: List of the countries in the sample

\begin{tabular}{|c|c|c|c|c|c|c|}
\hline \multicolumn{2}{|c|}{ Europe and North America } & \multirow{2}{*}{$\begin{array}{l}\text { Latin America } \\
\text { \& Caribbean } \\
\text { Argentina }\end{array}$} & \multirow{2}{*}{$\begin{array}{l}\text { Middle East \& } \\
\text { North Africa } \\
\text { Algeria }\end{array}$} & \multirow{2}{*}{$\begin{array}{l}\text { Sub-Saharan } \\
\text { Africa } \\
\text { Botswana }\end{array}$} & \multirow{2}{*}{$\begin{array}{l}\text { East Asia } \\
\text { China }\end{array}$} & \multirow{2}{*}{$\begin{array}{l}\text { South Asia } \\
\text { Bangladesh }\end{array}$} \\
\hline Austria & Australia & & & & & \\
\hline Belgium & Canada & Bolivia & Egypt & Cote d'Ivoire & Kong & India \\
\hline Bulgaria & New Zealand & Brazil & Iran & Ghana & Indonesia & Nepal \\
\hline Denmark & United States & Chile & Israel & Kenya & $\begin{array}{l}\text { Japan } \\
\text { Korea }\end{array}$ & Pakistan \\
\hline Finland & & Colombia & Jordan & Madagascar & South & Sri Lanka \\
\hline France & & Costa Rica & Morocco & Malawi & Malaysia & \\
\hline Germany & & Dominican Rep & Tunisia & Mauritius & Philippines & \\
\hline Greece & & Ecuador & Turkey & Nigeria & Singapore & \\
\hline Hungary & & El Salvador & & Rwanda & Taiwan & \\
\hline Ireland & & Guatemala & & Sierra Leone & Thailand & \\
\hline Italy & & Honduras & & South Africa & & \\
\hline Netherlands & & Jamaica & & Tanzania & & \\
\hline Norway & & Mexico & & Uganda & & \\
\hline Poland & & Panama & & Zambia & & \\
\hline Portugal & & Peru & & & & \\
\hline Romania & & Uruguay & & & & \\
\hline Spain & & Venezuela & & & & \\
\hline Sweden & & & & & & \\
\hline Switzerland & & & & & & \\
\hline United & & & & & & \\
\hline Kingdom & & & & & & \\
\hline
\end{tabular}


Table A6: MITs over 1960-2010: Countries and time duration (in years)

\begin{tabular}{|c|c|c|c|c|c|c|c|c|c|}
\hline $\begin{array}{l}\text { Latin America \& } \\
\text { Caribbean }\end{array}$ & & $\begin{array}{l}\text { Europe and } \\
\text { North America }\end{array}$ & & $\begin{array}{l}\text { Middle East \& } \\
\text { North Africa } \\
\end{array}$ & & Asia & & $\begin{array}{l}\text { Sub-Saharan } \\
\text { Africa }\end{array}$ & \\
\hline Jamaica & 41 & Bulgaria & 41 & Jordan & 41 & Malaysia & 33 & Mauritius & 32 \\
\hline Brazil & 41 & Hungary & 41 & Iran & 40 & & & & \\
\hline Peru & 41 & Romania & 39 & Turkey & 38 & & & & \\
\hline Panama & 41 & Poland & 38 & Tunisia & 36 & & & & \\
\hline Argentina & 41 & & & Algeria & 32 & & & & \\
\hline Costa Rica & 38 & & & Egypt & 31 & & & & \\
\hline $\begin{array}{l}\text { Dominican } \\
\text { Rep }\end{array}$ & 38 & & & Morocco & 31 & & & & \\
\hline Ecuador & 37 & & & & & & & & \\
\hline Guatemala & 36 & & & & & & & & \\
\hline Mexico & 32 & & & & & & & & \\
\hline
\end{tabular}

Table A7: List, definition and sources of the variables

\begin{tabular}{|lll|}
\hline Variables & Description & Source \\
\hline Investment rate & $\begin{array}{l}\text { Gross capital formation immobilized as } \\
\text { a percentage of GDP }\end{array}$ & World Development Indicator \\
\hline $\begin{array}{l}\text { Population } \\
\text { growth }\end{array}$ & Population growth (in percentage) & World Development Indicator \\
\hline $\begin{array}{l}\text { Dependency } \\
\text { ratio }\end{array}$ & $\begin{array}{l}\text { Age dependency ratio, young (in } \\
\text { percentage of working-age population) }\end{array}$ & World Development Indicator \\
\hline $\begin{array}{l}\text { Secondary/ } \\
\text { Tertiary } \\
\text { completion }\end{array}$ & $\begin{array}{l}\text { Percentage of population who have } \\
\text { completed secondary/tertiary education }\end{array}$ & Barro and Lee (2010) \\
\hline $\begin{array}{l}\text { Skill ratio } \\
\text { Ratio of tertiary schooling over }\end{array}$ & $\begin{array}{l}\text { Authors based on Barro and Lee } \\
\text { (2010) }\end{array}$ \\
\hline $\begin{array}{l}\text { Overall } \\
\text { concentration }\end{array}$ & $\begin{array}{l}\text { Theil export diversification index } \\
\text { (nternational Monetary Fund } \\
\text { (following } \\
\text { Cadot et al., 2011) }\end{array}$ \\
\hline $\begin{array}{l}\text { Intensive } \\
\text { margins }\end{array}$ & $\begin{array}{l}\text { Within-component of the Theil export } \\
\text { diversification index }\end{array}$ & $\begin{array}{l}\text { International Monetary Fund } \\
\text { (following } \\
\text { Cadot et al., 2011) }\end{array}$ \\
\hline $\begin{array}{l}\text { Extensive } \\
\text { margins }\end{array}$ & $\begin{array}{l}\text { Between-component of the Theil } \\
\text { export diversification index }\end{array}$ & $\begin{array}{l}\text { International Monetary Fund } \\
\text { (following } \\
\text { Cadot et al., 2011) }\end{array}$ \\
\hline $\begin{array}{l}\text { Trade openness } \\
\text { in percentage of GP) }\end{array}$ & $\begin{array}{l}\text { Penn World Table 8.1 (Alcala \& } \\
\text { Cicone 2014) }\end{array}$ \\
\hline
\end{tabular}


i The World Bank classifies countries in lower, middle income and higher income on the basis of gross national income per capita at current prices. In order for this income classification to reflect both monetary and non-monetary characteristics of well-being, the World Bank examines the relationship between measures of well-being, including the impact of poverty and child mortality, and GNI per capita.

ii Equatorial Guinea, Greece, Hong Kong, China, Ireland, Israel, Japan, Mauritius, Portugal, Puerto Rico, South Korea, Singapore, Spain and Taiwan.

iii Today, China, Malaysia and Thailand are regularly mentioned as countries that may be stuck into a middle-income trap.

iv About the distinction between relative and absolute income gaps, see Rosenblatt and Im (2013) and Agénor (2017).

v Jiang (2011) is particularly illustrative of this approach as he lists growing inequality, inefficient financial system, over-urbanization and growing spatial polarization, shortage of public services, unemployment and skill misallocation, corruption, social unrest and decreasing trust, electoral instability.

${ }^{\text {vi }}$ Various other studies have also focused on shock-related determinants to explain growth breakdowns in developing countries (Calvo, 1998; Becker and Mauro, 2006; Cerra and Saxena, 2008; Carrière-Swallow and Céspedes, 2013; Abiad et al., 2015). Still, whereas they are relevant for the explanation of short-term growth volatility, they are not useful to explain long-term trend volatility or MITs.

vii By contrast, poverty traps have been formally analyzed by various important theoretical contributions (Banerjee and Newman, 1993; Galor and Zeira, 1993; Azariadis, 2006)

${ }^{\text {viii }}$ For some middle-income countries, as China or Argentina, the demographic dividend may also progressively vanish with population aging and increased dependence ratios. 
${ }^{\text {ix }}$ About the distinction between relative and absolute income gaps, see Rosenblatt and Im (2013) and Agénor (2017).

x We use the Maddison (2010) database because it is very comprehensive, covering most countries over the period 1950-2010. GDP per capita is expressed in constant 1990 dollars We complete some series until 2010 using the GDP growth rate per capita (in local currency) measured at constant prices by the International Monetary Fund. In the absence of data, the following countries are excluded: the countries of the former Russian Federation; the countries of the former republics of Czechoslovakia and Yugoslavia; Cuba, North Korea, Puerto Rico, Somalia, the Palestinian territories and Trinidad and Tobago. In the end, we collect data from 132 countries from 1950 to 2010.

${ }^{x i}$ For a recent criticism of this approach, see Agénor (2017).

xii Despite the high degree of correspondence between the thresholds, some countries may not have the same classification as that of the World Bank.

xiii 14 intervals of $\$ 250$ for the low income segment ranging from $\$ 1.500$ to $\$ 4.750 \times 16$ intervals of $\$ 250$ for the lower middle-income segment ranging from $\$ 5,000$ to $\$ 8.750 \times 45$ intervals of $\$ 250$ for the lower middle-income segment ranging from $\$ 9,000$ to $\$ 20,000=$ 10,080 sets of thresholds. For example, the first set of threshold is given by the vector $(\$ 1,500 ; \$ 5,000 ; \$ 9,000)$ and the last $10080^{\text {th }}$ set is the vector $(\$ 4,750 ; \$ 8,750 ; \$ 20.000)$.

${ }^{\text {xiv }}$ Felipe et al (2012) distinguish between low middle-income and upper middle-income trap as well as between earlier and recent transitions. In our paper, we do not make such distinctions, plus we use the distribution of slowdown duration rather than the number of years as middle-income.

xv When the MIT driver $\mathrm{X}$ is extracted from the Z-vector, as in the section 4.1, the composition of the Z-vector of controls changes from one estimation to another. 
${ }^{x v i}$ Results are reported in the appendix section.

xvii Table A1's columns 6 confirms that a similar gap, albeit narrower, exists when the sample is extended to HICs.

xviii Quite surprisingly, human capital plays no part in this story. Tables A2 and A3 in Appendix show that, although tertiary schooling spurs growth in the extended sample not trapped, schooling levels or structure have no effect for the MICs, trapped or not, for the simultaneous and for the lagged models.

${ }^{\text {xix }}$ For the sake of convenience, subscripts $t-t+5$ were simplified to $t$.

xx As explained in Brambor et al. (2006), when complex interactions including two continuous variables are present in the model, the full marginal impact sums up all estimated impacts of $\mathrm{X}_{1}$, including those conditioned by the other continuous variable $\mathrm{X}_{2}$. In equation 2 , the full impact of $\mathrm{X}_{1}$ on GDP growth is given by $\alpha_{3}+\alpha_{8 *} \mathrm{X}_{2}$ outside the MIT and by $\alpha_{3}+\left(\alpha_{5}\right.$ $\left.+\alpha_{8}\right) * \mathrm{X}_{2}$ inside the MIT. They both vary with $\mathrm{X}_{2}$.

xxi The estimation results are available on demand.

xxii Outside of the MIT, the impact of a one standard deviation increase of the rate of population growth would lead to a .15 to .40 standard deviation increase of the GDP growth rate after the investment rate grows from 25 to $40 \%$. Inside the MIT, the same increase of the investment rate would lead to only a slight worsening from -1.0 to -1.2 percentage point of the adverse growth impact of population expansion (respectively .40 to .45 standard deviation).

xxiii Similar computation of the marginal growth impact of the dependency ratio at different levels of investment rate shows that the positive cumulative impact only holds outside the MIT and for very high levels of investment rate (30\% and higher) corresponding to the top $5 \%$ of the extended reference sample (composed of higher income countries and middle income countries not trapped). 
${ }^{\text {xxiv }}$ See Table A7 for the definition and measurement of these variables.

\section{References}

Abiad, A., Bluedorn, J., Guajardo, J. and Topalov, P. (2015) The rising resilience of emerging market and developing economies. World Development. Vol.72(1), 1-26.

Agénor, P. (2017) Caught in the middle? The economics of middle-income traps. Journal of Economic Surveys. Vol.31(3), 771-791.

Agénor, P. and Canuto, O. (2014) Access to finance, product innovation and middleincome traps. World Bank, Policy Research Working Paper.

Agénor P., Canuto, O. and Jelenic, M. (2012) Avoiding middle-income growth traps. World Bank, Policy Research Working Paper 6210.

Aiyar S., Duval R., Puy D., Wu Y. and Zhang L. (2013) Growth slowdowns and the middle-income trap. IMF Working Paper 71.

Alias N. Z., Hussein N., and Mohamad A. A. (2014). Malaysia's middle income trap truth or mythology? Malaysian Rating Corporation Berhad.

Aslund, A. (2013) Why Growth in Emerging Economies Is Likely to Fall. Working Paper Series WP13-10, Peterson Institute For International Economics.

Azariadis, C. (2006) The theory of poverty traps. What have we learned? in Bowles, S. and Durlauf, S. and Hoff, K. Eds. Poverty Traps. Princeton, N.J.. Princeton University Press, $17-40$. 
Banerjee, A. V. and Newman, A. F. (1993) Occupational choice and the process of development. Journal of Political Economy. Vol.101(2), 274-298.

[dataset] Barro, R. and Lee, J.-W. (2010) A new dataset of educational attainment in the world, 1950-(2010) Journal of Development Economic.. Vol. 104(C), 284-198.

Becker, T. and Mauro, P. (2006) Output drops and the shocks that matter. IMF Workin Paper, No. 06/172. Washington, DC: International Monetary Fund.

Berg, A., Ostry J. D. and Zettelmeyer, J. (2012) What makes growth sustained? Journal of Development Economics. Vol. 98(1), 149-166.

Bloom, D. E., Canning, D. and Sevilla, J. (2001) Economic growth and the demographic transition. RAND working paper 8685.

Brambor, T., Clark W. R., and Golder, M. (2006) Understanding interaction models: Improving empirical analyses, Political Analysis. Vol.14(1), 63-82.

Bulman, D., Eden, M. and Nguyen, H. (2015) Transitioning from low-income growth to high-income growth. Is there a middle income trap? World Bank, Policy Research Working Paper 7104, Washington DC : The World Bank.

Calvo, G. A. (1998) Capital flows and capital-market crises : the simple economics of sudden stops. Journal of Applied Economics. Vol. 1(1), 35-54.

Cadot O., Carrère C., and Strauss-Kahn V. (2011a). Export diversification: what's behind the hump? The Review of Economics and Statistics, MIT Press. Vol. 93(2), 590-605, May.

Cadot O., Carrère C., and Strauss-Kahn V. (2011b). Trade diversification: drivers and impacts. In: Jansen, M. \& Peters, R. \& Salazar-Xirinachs, J.-M. (Ed.). Trade and 
Employment: from Myths to Facts. Geneva : ILO-EC International Labour Office - European Commission, 253-307.

Campante, F. R. and Chor, D. (2012) Why was the Arab world poised for revolution? Schooling, economic opportunities and the Arab Spring. Journal of Economic Perspectives. Vol. 26(2), 167-188.

Carrière-Swallow, Y. and Céspedes, L. (2013) The impact of uncertainty shocks in emerging economies. Journal of International Economics. Vol. 90(2), 316-325.

Cerra. V. and Saxera, S. C. (2008) Growth Dynamics: The myth of economic recovery. American Economic Review. Vol. 98(1), 439-457.

Daude, C. and Frenandez-Arias, E. (2010) On the role of productivity and factor accumulation in economic development. IDB Working Paper Series. No. IDB-WP-155.

Doner, R. and Schneider, B. R. (2016) The Middle Income Trap: more politics than economics. World Politics. Vol. 68(4), 608-644.

Eichengreen, B., Park, D., and Shin, K. (2012). When fast growing economies slow down: international evidence and implications for China. Asian Economic Papers. Vol. 11(1): $42-87$.

Eichengreen, B., Park, D., and Shin, K. (2014). Growth slowdowns redux. Japan and the World Economy. Vol. 32(1): 65-84.

Fang, C. (2012) Is there a "Middle-income Trap"? theories, experiences and relevance to China. China \& World Economy. Vol. 20(1), 49-61. 
Felipe, J. (2012) Tracking the Middle-Income Trap: What is It, Who is in It and Why? Part 1. ADBI Economics Working Paper Series No. 306, Asian Development Bank, Washington DC.

Felipe, J. (2012) Tracking the Middle-Income Trap: What Is It, Who Is In It and Why? Part 2. ADBI Economics Working Paper Series No. 307, Asian Development Bank, Washington DC.

Flaaen A., Ghani E. and Mishra S. (2007) How to Avoid Middle Income Traps? Evidence From Malaysia. World Bank Working Research Paper 6427.

Furuoka, F. and Munir, Q. (2011) Can population growth contribute to economic development? New evidence from Singapore. Economics Bulletin. Vol. 31(4)

Galor, O. and Zeira, J. (1993) Income distribution and macroeconomics. Review of Economic Studies. Vol. 60(1), 35-52.

Gill, I. S., Kharas, H. J. and others. (2007) An East Asian renaissance: ideas for economic growth. Washington DC: World Bank.

Gill, I. S., and Kharas, H. J. (2015) The Middle Income Trap turns ten. World Bank Policy Research Working Paper 7403. Washington DC: World Bank.

Han, X., and Wei, S.-J. (2017) Re-examining the middle-income trap hypothesis (MITH): What to reject and what to revive? Journal of International Money and Finance. Vol. 73 (PA), 41-61.

Hausmann, R. and Rodrik, D. (2003) Economic development as self-discovery. Journal of Development Economic, Vol.72(2), 603-633. 
Hausmann R., Pritchett, L. and Rodrik D. (2006) Growth accelerations. Journal of Economic Growth, Vol. 10(4), 303-329.

Hausmann, R., Rodríguez, F., and Wagner, R. (2008). Growth collapses. In Reinhart, C.. Velasco, A. and Vegh, C. (eds). Money, Crises, and Transition: Essays in Honor of Guillermo Calvo. Cambridge, MIT Press.

Imbs, J. and Wacziarg, R. (2003) Stages of diversification. The American Economic Review. Vol. 93(1), 63-86.

Jankowska, A., Nagengast, A. and Perea, J. R. (2012) The product space and the Middle-Income Trap: comparing Asian and Latin American experiences, OECD Workin Paper, No 311.

Jiang, S. (2011) The 'Middle Income Trap' Is A Meaningless Question. CSSN, 15 December (2011)

Jimenez, E., Nguyen. V. and Patrinos, H. A. (2012) Stuck in the middle? Human capital development and economic growth in Malaysia and Thailand. World Bank Policy Research Working Paper 6283.

Kanchoochat. V. and Intarakumnerd, P. (2014) Tigers trapped: tracing the MiddleIncome Trap through the East and Southeast Asian experience. Berlin Working Papers On Money, Finance, Trade and Development.

Kharas, H. and Kohli, H. (2011) What is the Middle-Income Trap, why do countries fall into It and how can It be avoided? Journal of Emerging Market Economies. Vol. 3(3), 281-289. 
Kharas, H., Zeufack, A. and Majeed H. (2010) Cities, people and the economy: a study on positioning Penang. Khazanah Nasional Berhad and The World Bank.

Lectard, P., and Rougier, E. (2018). Can developing countries gain from defying comparative advantage? Distance to comparative advantage, export diversification and sophistication, and the dynamics of specialization. World Development. Vol. 102(C), 90-110.

Leff, N. H. (1969) Economic development through bureaucratic corruption. American Behavioral Scientis. Vol. 8(3), 8-14.

Lin, J. Y. (2009) Economic development and transition: Thought, strategy, and viability. Cambridge University Press.

Lin, J. Y. (2012) New structural economics: A framework for rethinking development. Washington DC: The World Bank Publications.

Lin, J. Y. and Treichel. V. (2012) Learning from China's rise to escape the MiddleIncome Trap. A new structural economics approach to Latin America. World Bank Policy Research Working Paper.

McMillan, M. and Rodrik, D. (2011) Globalisation, structural change and productivity growth. NBER Workin Paper, No 17143.

McMillan, M., Rodrik, D and I. Verduzco-Gallo. (2014) Globalization, structural change and productivity growth, with an update on Africa. World Development. Vol. 63(C), $11-32$.

Melitz, M. (2003) The impact of trade on intra-industry reallocations and aggregate industry productivity. Econometrica. Vol. 71 (6): 1695-1725. 
Nicita, A., Shirotori, M., and Klok, B. T. (2013) Survival analysis of the exports of least developed countries: The role of comparative advantage. UNCTAD Blue Series Papers 54. United Nations Conference on Trade and Development.

Nungsari, A. R. and A. G. Zeufack. (2009) “Escaping the Middle-Income Trap.” In Readings on Development: Malaysia 2057. Khazanah Nasional Berhad.

Pritchett, L. (2000) Patterns of economic growth: hills, plateaus, mountains and plains. World Bank Economic Review. Vol. 14(2), 221-250.

Pritchett, L. and Summers, R. (2014) 'Asiaphoria' meets regression to the means. NBER Workin Paper, No 20573. Cambridge, MA: The National Bureau of Economic Research.

Ray, D. (2010) Uneven growth: A framework for research in development economics. Journal of Economic Perspectives. Vol. 24(3), 45-60.

Reddy, S. and Minoiu, C. (2007) Real income stagnation of countries, 1960 - (2001) Journal of Development Studies. Vol. 45(1), 1-23.

Robertson, P. E. and Ye L. (2013) On the existence of a Middle Income Trap. Economics Discussion/Working Papers 13-12. The University of Western Australia. Department of Economics.

Rodriguez, F. (2008) An empirical test of the poverty traps hypothesis. International Poverty Center. Technical Paper No.4.

Rodrik, D. (1999) Where Did All The Growth Go? External shocks, social conflict and growth collapses. Journal of Economic Growth. Vol. 4(4),185-212. 
Rosenblatt, D. and Im, F. G. (2013) Middle-Income Traps: a conceptual and empirical survey. World Bank Policy Research Working Paper, No 6594.

Rougier, E. (2016) "Fire in Cairo": authoritarian-redistributive social contracts, structural change and the Arab Spring. World Development. Vol. 78, pp. 148-171.

Schott, P. K. (2003) One size fits all? Hecksher-Ohlin specialization in global production. The American Economic Review. Vol.93(3), 686-708.

Spence, M. (2011) The next convergence. The future of economic growth in a multispeed world. New York: Farrar, Straus and Giroux.

Udomsaph, C. and Zeufack, M. (2010) Skills shortages and the Middle-Income Trap: micro-econometric evidence from Malaysian manufacturing. Khazanah Research and Investment Strategy Special Report.

UNIDO (2010b) Emerging patterns of manufacturing structural change. Working Paper 04/(2010) Vienna: United Nations Industrial Development Organisation.

Van Der Ven, R. and Smits J. (2011) The demographic window of opportunity: age structure and sub-national economic growth in developing countries. NiCE Working Paper $11-102$

Williamson, J. (2011) Some basic disagreements on development. Peterson Institute For International Economics.

Woo, W.T. (2009) Getting Malaysia out of the Middle-Income Trap. Mimeo, University of California, Davis - Department of Economics. 